\title{
Advances in selective catalytic transformation of ployols to value-added chemicals
}

\author{
MA Jiping a, YU Weiqiang a, WANG Min a, JIA Xiuquan ${ }^{\mathrm{a}, \mathrm{b}}$, LU Fang a ${ }^{\mathrm{a}}$, XU Jie ${ }^{\mathrm{a}, *}$ \\ a Dalian National Laboratory for Clean Energy, State Key Laboratory of Catalysis, Dalian Institute of Chemical Physics, Chinese Academy of Sciences, \\ Dalian 116023, Liaoning, China \\ b University of Chinese Academy of Sciences, Beijing 100049, China
}

\section{A R T I C L E I N F O}

\section{Article history:}

Received 2 November 2012

Accepted 14 December 2012

Published 20 March 2013

\section{Keywords:}

Biomass

Catalysis

Furan derivative

Polyol

Renewable resource

\begin{abstract}
A B S T R A C T
In this review, we discuss recent progress in the catalytic transformation of polyols to value-added chemicals, including 5-hydroxymethylfurfural (HMF), ethylene glycol (EG), 1,2-propylene glycol (1,2-PG) and 1,3-propylene glycol (1,3-PG). The challenges and solving of the synthesis of HMF from different carbohydrates, such as fructose, glucose and cellulose are analyzed. For the conversion of HMF, we focus on the catalytic oxidation of HMF to 2,5-diformylfuran and 2,5-furandicarboxylic acid and their applications to polymers. Advances in the catalytic hydrogenolysis of polyols including cellulose, sugar alcohols and glycerol to diols such as EG, 1,2-PG and 1,3-PG are reviewed, and the reaction mechanisms were discussed. Research topics are suggested for future research from this review on the selective catalytic transformation of ployols to value-added chemicals.
\end{abstract}

(C) 2013, Dalian Institute of Chemical Physics, Chinese Academy of Sciences. Published by Elsevier B.V. All rights reserved.

\section{Introduction}

Diminishing fossil fuel reserves and the adverse effects of their use on the global environment and climate are of major academic, economic and political concerns. To solve the energy and environmental problems, the catalytic conversion of biomass resources into non-petroleum derived fuels and chemicals is attractive [1-12]. Biomass is obtained from biological photosynthesis using readily available atmospheric $\mathrm{CO}_{2}$, water and sunlight and it is abundant in nature. It is not only an energy carrier but also a renewable organic carbon source. The use of biomass as feedstocks for the production of fuels and chemicals is necessary for a sustainable chemistry industry [13].

Carbohydrates with plentiful oxygen atoms and long carbon chains are the main components of plant-derived biomass. The direct transformation and utilization of carbohydrates are very difficult because of the strong hydrogen bonds in them. A useful way to get selected chemicals from them is by catalytic dehydration and hydrogenolysis.

In this review, we discuss recent progress on the transformation of polyols to selected value-added chemicals by dehydration and hydrogenolysis processes. We focus on the dehydration of carbohydrates to 5-hydroxymethylfurfural (HMF) and its further conversion to 2,5-diformylfuran (DFF) and 2,5-furandicarboxylic acid (FDCA) by selective oxidation. Progress in the catalytic hydrogenolysis of polyols including cellulose, sugar alcohols and glycerol to diols such as ethylene glycol (EG), 1,2-propylene glycol (1,2-PG) and 1,3-propylene glycol $(1,3-P G)$ is reviewed.

\section{Catalytic conversion of carbohydrates to HMF}

HMF is a versatile platform chemical that is readily obtained

* Corresponding author. Tel/Fax: +86-411-84379245; E-mail: xujie@dicp.ac.cn This work was supported by the National Natural Science Foundation of China $(21233008,21203183$, and 21103174). DOI: 10.1016/S1872-2067(11)60501-9 | http://www.sciencedirect.com/science/journal/18722067 | Chin. J. Catal., Vol. 34, No. 3, March 2013 


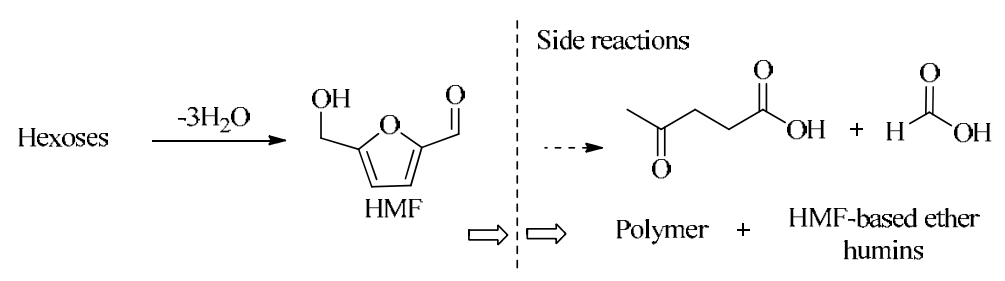

Fig. 1. Production of HMF and side reactions [19].

by the dehydration of six-carbon containing sugars [14]. Its selective oxidation products, such as DFF and FDCA, are important polymeric monomers, especially for FDCA, which is a promising alternative to petroleum-based terephthalic acid (PTA). Levulinic acid (LA), the rehydration product of HMF, and its derivatives were reviewed very recently by $\mathrm{Wu}$ and coworkers [15]. The reduction products of $\mathrm{HMF}$, including 2,5-dimethylfuran (DMF), 2,5-dimethyltetrahydrofuran, 2,5-bis (hydroxymethyl)furan and 2,5-bis(hydroxymethyl)tetrahydrofuran, are biofuels or biofuel additives [16]. However, because there are few works published on the synthesis of DMF since a review in 2011 [17], LA and its derivatives and the reduction products of HMF will not be discussed in this review.

Since the last decade of the 19th century, growing interests have been paid to HMF. Intensive investigations have produced the correct structure, synthesis methods, and physical and chemical properties. At present, the main method to synthesize HMF is the conversion of carbohydrates, such as fructose, glucose, sucrose, inulin and cellulose, by catalysis using Brönsted acids or Lewis acids. Several recent reviews focused on the catalyst or solvent systems [18-29]. There are few discussions of the challenges and solving of the synthesis of HMF from different carbohydrates. In this review, we focus our discussion on the difficulties, challenges and solving of the synthesis of HMF from different structural hexoses.

\subsection{From fructose}

The production of HMF from fructose is easy compared with other hexoses. Two main side reactions (Fig. 1) exist in the dehydration of sugar to HMF [19]. One is the rehydration of HMF to levulinic acid and formic acid. This side reaction can be avoided in anhydrous systems. The other is the polymerization or cross-polymerization of HMF or intermediates to insoluble humins. Unfortunately, this type of side reactions cannot be avoided either in aqueous systems or anhydrous systems. Therefore, the key to the efficient synthesis of HMF is the design of novel efficient catalysts or reaction media to suppress these side reactions, or the timely removal of HMF or water from the acidic catalytic systems.

The design of novel catalysts is a way to enhance the yield of HMF. A novel carbon-based solid acid (Glu-TsOH) prepared from glucose and $p$-toluenesulfonic acid, reported by Wang et al. [30] in 2011, is one of the most efficient catalysts for the conversion of fructose into HMF. The yield of HMF was as much as $91 \%$ using dimethyl sulfoxide (DMSO) as solvent at $130{ }^{\circ} \mathrm{C}$ after $1.5 \mathrm{~h}$. This remarkable performance was ascribed to a better affinity to fructose and a synergic effect between surface carboxylic acid and the sulfonic acid groups. Yang et al. [31] also reported an efficient catalyst, which is tantalum hydroxide treated with phosphoric acid (TA-p). The yield of HMF (90\%) was obtained in a water/2-butanol biphasic system at $160{ }^{\circ} \mathrm{C}$ after $100 \mathrm{~min}$, and there was no loss in activity after reuse for 15 times.

The reaction medium plays a big role in fructose dehydration. Bicker et al. [32] investigated sulphuric acid catalyzed fructose dehydration in sub- and supercritical fluids, such as supercritical acetone-water $(90 / 10, v / v)$, and obtained $99 \%$ conversion with $77 \%$ selectivity for HMF. They found no solid byproducts in the sub- or supercritical solvents. In 2006, Moreau et al. [33] reported that the ionic liquid 1-H-3-methylimidazolium chloride can act as a catalyst and solvent at the same time. The yield of HMF was as much as $92 \%$ at $90{ }^{\circ} \mathrm{C}$ in $45 \mathrm{~min}$. Li et al. [34] obtained 97\% HMF yield in 8 min using 1-butyl-3-methylimidazolium chloride ([BMIM]Cl) with $9 \mathrm{~mol} \%$ hydrochloric acid catalyst. A fructose conversion of $98.6 \%$ with a $\mathrm{HMF}$ yield of $83.3 \%$ was achieved in $10 \mathrm{~min}$ reaction time at $80{ }^{\circ} \mathrm{C}$ in $[\mathrm{BMIM}] \mathrm{Cl}$ using a sulfonic ion exchange resin as catalyst [35]. Very recently, Lai and coworkers [36] reported that alcohol, esp. isopropyl alcohol, is an efficient and green system for fructose dehydration that gave $83 \%$ yield of $\mathrm{HMF}$ at $120{ }^{\circ} \mathrm{C}$ in $2 \mathrm{~h}$. Alcohol as the solvent not only can suppress the rehydration of HMF but also can make the separation of HMF from the reaction system easier.

The timely removal of product or water from the acid catalytic reaction medium is another way to increase the yield of HMF. In 2006, Dumesic and coworkers [37] reported a highly efficient water-organic biphasic system for the synthesis of HMF from fructose (Fig. 2). The $\mathrm{HCl}$ catalyzed dehydration of fructose proceeded in the aqueous phase and the product HMF was efficiently and rapidly extracted into the methyl isobutyl ketone (MIBK) organic phase, thus preventing the rehydration

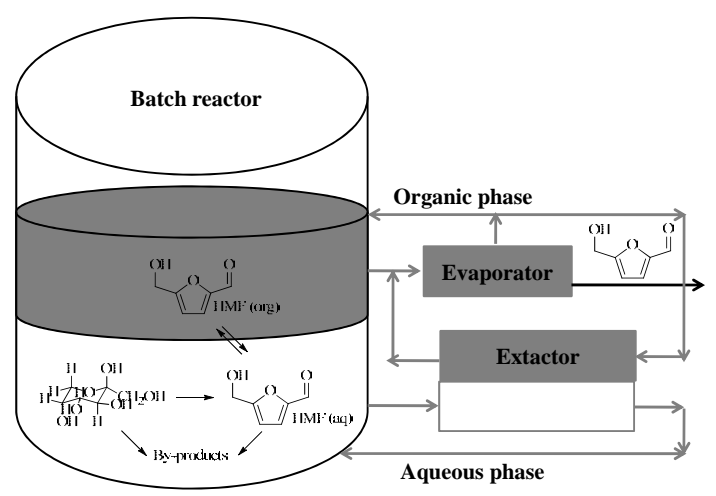

Fig. 2. Production of HMF from D-fructose with countercurrent extraction and evaporation steps (the aqueous phase contains fructose, DMSO, PVP, and catalyst; the organic phase contains MIBK and 2-butanol) [37]. 
of HMF. For example, $80 \%$ conversion of fructose with $75 \%$ selectivity to HMF was obtained using water/DMSO $(8 / 2, w / w)$ as the aqueous phase and MIBK/2-butanol $(7 / 3, w / w)$ as the organic phase at $180{ }^{\circ} \mathrm{C}$ in $2.5-3 \mathrm{~min}$. The addition of an inorganic salt to the aqueous phase can increase the distribution ratio of HMF in the organic phase by the salting-out effect [38]. Among the different organic solvents, including primary alcohol, secondary alcohol, ketone and cyclic ether, tetrahydrofuran showed the best performance with a selectivity to HMF as much as $83 \%$. The removal of water also can suppress undesired reactions, e.g., rehydration of HMF or the condensation of partially dehydrated intermediates. Shimizu et al. [39] reported two ways to execute this idea: one is to use mild evacuation at 0.097 MPa, and the other is to decrease the particle (bead) size of the resin (Amberlyst-15). Both ways efficiently increased HMF yield in fructose dehydration.

A reduced reaction time is one solution to circumvent the two side reactions to enhance HMF yield. A microreactor has the advantage of a short reaction time and the same residence time of feedstocks and products. In 2009, Tuercke et al. [40] using a microreactor continuous equipment instead of a batch reactor, showed that at $185^{\circ} \mathrm{C}$ under $1.7 \mathrm{MPa} \mathrm{O}_{2}$ pressure, after 1 min the conversion of fructose was as much as $99 \%$ with 99\% selectivity for HMF. A highly efficient heating method can reduce the reaction time. Compared with conventional heating methods, such as oil or sand bath heating, microwave irradiation can give a fast heating rate and can avoid the partial overheating that can exist under conventional oil bath conditions. Qi et al. [41] described that fructose conversion and HMF yields with microwave heating ( $91.7 \%$ and $70.3 \%$, respectively) were higher than those with sand bath heating $(22.1 \%$ and $13.9 \%$ respectively) under the same conditions. Li et al. [42] found that the combination of an ionic liquid and microwave irradiation is an efficient system for the dehydration of highly concentrated fructose to form HMF in the absence of a catalyst.

\subsection{From glucose}

Compared with fructose, glucose has the advantages of abundance and low cost. However, the rate of glucose dehydration and the selectivity for HMF are low. Therefore, the synthesis of HMF from glucose is a more challenging topic. At present, most researchers believed that there are three stages in the glucose dehydration process. First, there is $\alpha$-glucopyranose mutarotation to $\beta$-glucopyranose via a linear aldose structure, then there is $\beta$-glucopyranose isomerization to fructofuranose via a linear enol structure, and finally, there is fructofuranose dehydration to HMF. The mutarotation and isomerization processes are the key steps in glucose dehydration. In reported works, there are three types of catalyst for the key steps, including a Lewis acid, base and glucose isomerase.

Lewis acids such as $\mathrm{CrCl}_{2}$ [43-47], $\mathrm{CrCl}_{3}$ [44-46,48,49], $\mathrm{SnCl}_{4}$ [50], $\mathrm{SnCl}_{2}$ [51], $\mathrm{GeCl}_{4}$ [52] in ionic liquid, and $\mathrm{AlCl}_{3}$ in a water/2-sec-butylphenol biphasic system [53], Sn- $\beta$ zeolite in saturated aqueous salt solutions at low pH [54], Sn-Mont in the single phase medium of tetrahydrofuran/DMSO [55], a composite of $\mathrm{MgCl}_{2}$ with silica gel in acetonitrile [56], and wa- ter-compatible lanthanide-based Lewis acids [57] can promote glucose isomerization to fructose. In 2007, Zhao et al. [43] reported an efficient method to synthesize HMF from glucose catalyzed by $\mathrm{CrCl}_{2}$ in 1-ethyl-3-methyl- imidazolium chloride ([EMIM]Cl) that gave $70 \%$ yield of HMF. It was proposed that the mutarotation of $\alpha$-glucopyranose to $\beta$-glucopyranose and the isomerization of $\beta$-glucopyranose to fructofuranose were realized via the effect of hydrogen bond action and complexing action with the help of [EMIM] $\mathrm{CrCl}_{3}$. A year later, Yong et al. [44] found that $\mathrm{N}$-heterocyclic carbene (NHC) promoted catalyst system, $\mathrm{NHC} / \mathrm{Cr}^{2+}$ (or $\mathrm{Cr}^{3+}$ ), in the ionic liquid 1-butyl-3-methylimidazolium chloride ([BMIM]Cl) can efficiently convert glucose to $\mathrm{HMF}$ with a yield of $81 \%(78 \%)$. IIgen et al. [46] reported that $\mathrm{CrCl}_{2}$ (or $\mathrm{CrCl}_{3}$ ) in choline chloride also can catalyze glucose to HMF with a yield of $45 \%$ (31\%).

$\mathrm{CrCl}_{2}$ or $\mathrm{CrCl}_{3}$ displayed good performance in the conversion of glucose to HMF in ionic liquid. However, its practical application is limited because of the toxicity of Cr. A lower toxicity or nontoxic catalytic system for the synthesis of HMF is more promising. In 2009, Han and coworkers [50] found that the Lewis acid $\mathrm{SnCl}_{4}$ can convert glucose to $\mathrm{HMF}$ in 1-ethyl-3-methylimidazolium tetrafluoroborate ([EMIM] $\mathrm{BF}_{4}$ ). Under optimized conditions, the yield of $\mathrm{HMF}$ was $61 \%$. ${ }^{1} \mathrm{H}$ NMR and HPLC were used to confirm the isomerization process of glucose to fructose. New evidence indicated that the formation of a five-membered ring chelate complex of the Sn atom and glucose may play a key role in the formation of HMF. Following this work, solid Lewis acids, such as Sn- $\beta$ and Sn-Mont catalysts were reported by Nicolla et al. [54] and Wang et al. [55], respectively. The $\mathrm{GeCl}_{4} /[\mathrm{BMIM}] \mathrm{Cl}$ catalytic system reported by Zhao and coworkers also exhibited good performance [52]. Stahlberg et al. [58] found that a catalytic system of lanthanide metal salts in ionic liquid such as $\mathrm{Yb}(\mathrm{OTf})_{3} /[\mathrm{BMIM}] \mathrm{Cl}$ can convert glucose to HMF. The authors believed that the mechanism of the lanthanide catalyst was different from the $\mathrm{Cr}$ salts in ionic liquid. Very recently, as much as $62 \%$ and $70 \%$ HMF yields were obtained, catalyzed by $\mathrm{AlCl}_{3} / \mathrm{HCl}$ [53] and $\mathrm{MgCl}_{2}$ with silica gel [56], respectively. A moderately high HMF yield of $42 \%$ was obtained under near-neutral conditions $(\mathrm{pH}=5.5)$ using water-compatible lanthanide-based Lewis acids as catalysts [57].

A base is another type catalyst for the isomerization of glucose to fructose. Takagaki et al. [59] reported a combination catalyst of a solid base and solid acid for the synthesis of HMF from glucose. First, the isomerization of glucose was catalyzed by the solid base hydrotacite (HT), and then the intermediate product fructose was converted to HMF using the solid acid Amberlyst-15 as catalyst. The conversion of glucose was $60 \%$ and the yield of HMF was $46 \%$. This catalytic system also can catalyze sucrose and cellobiose to HMF using DMF as solvent. $58 \%$ and $52 \%$ conversion with $93 \%$ and $67 \%$ selectivity for $\mathrm{HMF}$ were obtained at $120{ }^{\circ} \mathrm{C}$ after $3 \mathrm{~h}$, respectively. Both acidic sites and basic sites are present on the surface of $\mathrm{m} / \mathrm{c}-\mathrm{ZrO}_{2}$ and $\alpha-\mathrm{TiO}_{2}$, which favor the conversion of glucose into HMF. Especially, the existence of plentiful basic sites on the surface of $\mathrm{m} / \mathrm{c}-\mathrm{ZrO}_{2}$ can catalyze the isomerization of glucose to fructose 
[60,61]. More recently, Yan et al. [62] reported the catalytic conversion of glucose to $\mathrm{HMF}$ over $\mathrm{SO}_{4}{ }^{2-} / \mathrm{ZrO}_{2}$ and $\mathrm{SO}_{4}{ }^{2-} / \mathrm{ZrO}_{2}-\mathrm{Al}_{2} \mathrm{O}_{3}$ catalysts in DMSO. The yield of $\mathrm{HMF}(48 \%)$ was obtained with the $\mathrm{Zr} / \mathrm{Al}$ molar ratio of 1 at $130{ }^{\circ} \mathrm{C}$ in $4 \mathrm{~h}$.

Glucose isomerase also can efficiently convert glucose to fructose. In 2010, Huang et al. [63] examined the combination of an enzyme and acid catalyst for converting glucose to HMF. They found that boric acid can promote the isomerization of glucose to fructose which was dehydrated to HMF catalyzed by $\mathrm{HCl}$. A HMF yield of $63 \%$ was achieved at $190{ }^{\circ} \mathrm{C}$ in $45 \mathrm{~min}$. A $\mathrm{HMF}$ yield of as much as $42 \%$ from glucose and as much as $66 \%$ from sucrose were reported by Stanhlberg et al. in imidazolium-based ionic liquids with boric acid as a promoter [64].

\subsection{From cellulose}

Cellulose is the most abundant component in biomass resources. However, it is hard to dissolve cellulose in water or common organic solvents due to the strong hydrogen bond interaction between the molecular chains. The degradation of cellulose usually needs harsh conditions, and the practical application is prohibited by the inefficient process. Therefore, the key factor in the efficient utilization of cellulose is to destroy the hydrogen bond between the molecular chains to promote its dissolution in solvents. The synthesis of HMF from cellulose is a most challenging work and a multifunctional catalytic system for dissolution, hydrolyzation, isomerization, and dehydration is needed.

Increasing attention has been paid to the use of an ionic liquid as the medium for cellulose conversion due to the useful properties of an ionic liquid, such as thermal stability, chemical stability, solubility, strong polarity, non-volatility, and especially its catalytic properties for many reactions [49, 65-70]. In 2002, Rogers and coworkers [71] reported that the ionic liquid [AMEM]Cl can dissolve cellulose. Then Schuth and coworkers [72] found that cellulose can be degraded to glucose catalyzed by a solid acid.

$\mathrm{Su}$ et al. [73] investigated the synthesis of HMF from cellulose using a $\mathrm{CuCl}_{2}-\mathrm{CrCl}_{2}$ combined catalyst in ionic liquid [EMIM]Cl. The yield of HMF was 55\%. Qi et al. [74] reported a two-step method of the synthesis of HMF from cellulose using the ionic liquid [EMIM]Cl as solvent. A small amount of water was added step by step to enhance the stability of the intermediate glucose product under the reaction conditions. The hydrolyzation of cellulose was catalyzed by acidic resin. The acidic resin was removed before the addition of the Lewis acid $\mathrm{CrCl}_{3}$. Then, the in situ generated glucose was converted to HMF with a yield of $73 \%$ under optimized conditions. Zhang et al. [75] found that the water in an ionic liquid-water system was not only a solvent of the cellulose but also a reactant of cellulose hydrolyzation as well as a catalyst. The reduced sugars yield was as much as $97 \%$ at $140{ }^{\circ} \mathrm{C}$ in $3 \mathrm{~h}$ when 4 equivalent water was added. Moreover, cellulose can be directly converted to $\mathrm{HMF}$ in the presence of $\mathrm{CrCl}_{2}$. Zhao and coworkers [49] studied a microwave-assisted method to enhance the rate of degradation of cellulose in the ionic liquid using $\mathrm{CrCl}_{3}$ as catalyst. The HMF yield was $62 \%$ after $2 \mathrm{~min}$ at the microwave power of $400 \mathrm{~W}$. Wu et al. [76] also investigated microwave-assisted Lewis acid $\mathrm{CrCl}_{3}$ catalyzed cellulose to $\mathrm{HMF}$ and reported 55\% yield of HMF under optimized conditions. The catalytic systems reported by Binder and Raines [77] can directly convert untreated corn stalk to $\mathrm{HMF}$ with a $\mathrm{HMF}$ yield of $48 \%$ catalyzed by $10 \mathrm{~mol}^{2} \mathrm{CrCl}_{3}$ and $10 \mathrm{~mol} \% \mathrm{HCl}$ using DMA-LiCl/[EMIM]Cl as solvent.

\subsection{Proposed pathway of hexose dehydration}

A pathway of fructose dehydration to HMF was first reported by Haworth and Jones in 1944 [78]. From then on, two views on the pathway of six-carbon sugar dehydration were considered (Fig. 3). One was the cyclic pathway via the intermediate of frutofuranosyl. The other was the acyclic pathway via the intermediate of enol. Antal et al. [79] and Newth et al. [80] inferred that the synthesis of HMF from fructose was via the cyclic intermediates. The reasons were: a) it is easy to convert 2,5-anhydro-D-mannose (the enol intermediate of the cyclic dehydration pathway) to HMF, b) synthesis of HMF from fructose is easy but from glucose it is very hard, and c) when the reaction was performed in deuterated water, no carbon-deuterium bond was formed in the structure of HMF,

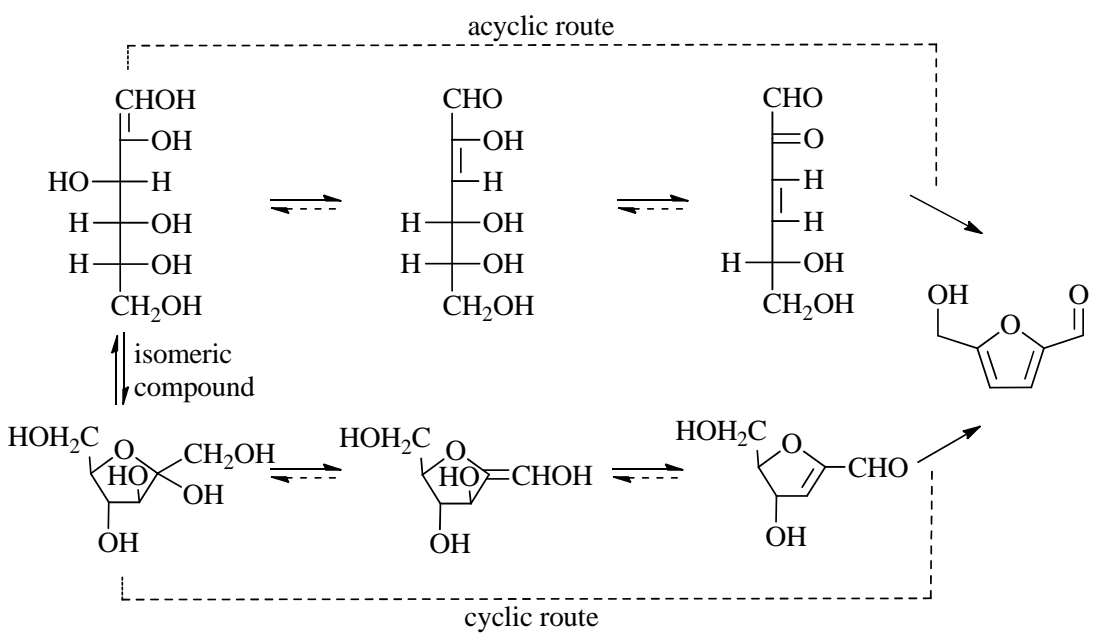

Fig. 3. Mechanism for the dehydration of hexoses [19]. 

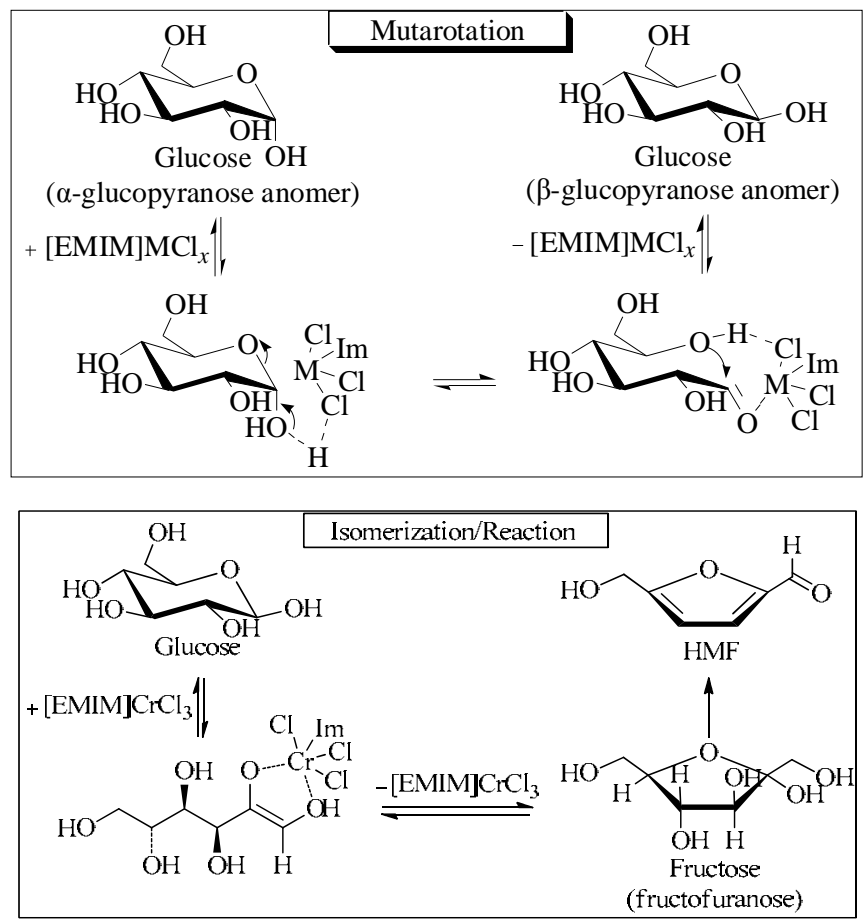

Fig. 4. Interactions between metal halide and glucose in [EMIM]Cl [43].

which was formed via keto-enol tautomerism in the acyclic pathway. Also, the $(4 R, 5 R)$-4-hydroxy-5-hydroxymetyl-4,5dihydrofuran-2-carbalde-hyde intermediate was identified from the ${ }^{1} \mathrm{H}$ and ${ }^{13} \mathrm{C}$ NMR spectra reported by Amarasekara and coworkers [81].

Mutarotation and isomerization (Fig. 4) are the key steps in the process of glucose conversion when an ionic liquid is used as the solvent and in the presence of a catalytic amount of the Lewis acid metal chloride [43]. $\alpha$-Glucopyranose was first converted to $\beta$-glucopyranose via single-nuclear $\alpha$-glucopyranose$[\mathrm{EMIM}] \mathrm{MCl}_{x}$ and straight glucose-[EMIM] $\mathrm{MCl}_{x}$ complexes. After that, $\beta$-glucopyranose was isomerized to fructofuranose via the linear enol structure of a single nucleus straight glucose-[EMIM] $\mathrm{CrCl}_{3}$ complex. Then fructofuranose was finally converted to HMF. The intermediate fructose was also detected by Han and coworkers [50] and Zhao and coworkers [52]. However, the complexes formed during glucose isomerization to fructose only consist of glucose and metal chloride. In 2010, Pidko et al. [47] further confirmed that in the presence of $\mathrm{CrCl}_{2}$, the facile reactions of sugar ring opening and closure involve coordination to a single $\mathrm{Cr}$ center. The rate determining H-shift reaction was facilitated by the self-organization of the Lewis acidic $\mathrm{Cr}^{2+}$ centers into a binuclear complex with the open form of glucose, which was due to the dynamic nature of the Cr complexes and the presence of moderately basic sites in the ionic liquid. X-ray absorption (XAS) data showed that there was no chemical bond formation between the metal centers and cati- onic [RMIM] ${ }^{+}$part of the ionic liquid solvent. Theoretical results were in good agreement with the experimental XAS data [82]. Stahlber et al. [64] reported metal-free dehydration of glucose to HMF with boric acid as the promoter. Deuterium-labeling studies elucidated that the isomerization proceeded via an ene-diol mechanism.

For solid Lewis acids, such as Sn- $\beta$ and Sn-Mont, that catalyzed glucose isomerization to fructose, it has been established that an intramolecular hydride shift occurred [54,55,83]. Base catalyzed isomerization takes place by a proton transfer mechanism through a series of enolate intermediates generated after the deprotonation of the $\alpha$-carbonyl carbon in water, which is known as the Lobry de Bruyn-van Ekenstein transformation $[59,83]$.

\section{Catalytic oxidation of HMF to furan derivatives}

The oxygenated derivatives of HMF are very important. Representative oxygenated products are 5-hydroxymethyl-2furancarboxylic acid (HMFCA), DFF, 5-formyl-2-furancarboxylic acid (FFCA), and FDCA (Fig. 5). Here we mainly review the synthesis of DFF and FDCA, and also take their applications to polymers into consideration.

\subsection{Catalytic oxidation of HMF to DFF}

DFF is one of the important oxygenated products of HMF. It<smiles>O=Cc1c[pH]cc1C=O</smiles>

DFF<smiles>O=C(O)c1ccc(CO)o1</smiles>
HMFCA<smiles>O=Cc1ccc(C(=O)O)o1</smiles><smiles>C1CCCCC1</smiles><smiles>CC(=O)c1ccc(C(=O)O)o1</smiles>

Fig. 5. Products of HMF oxidation. 


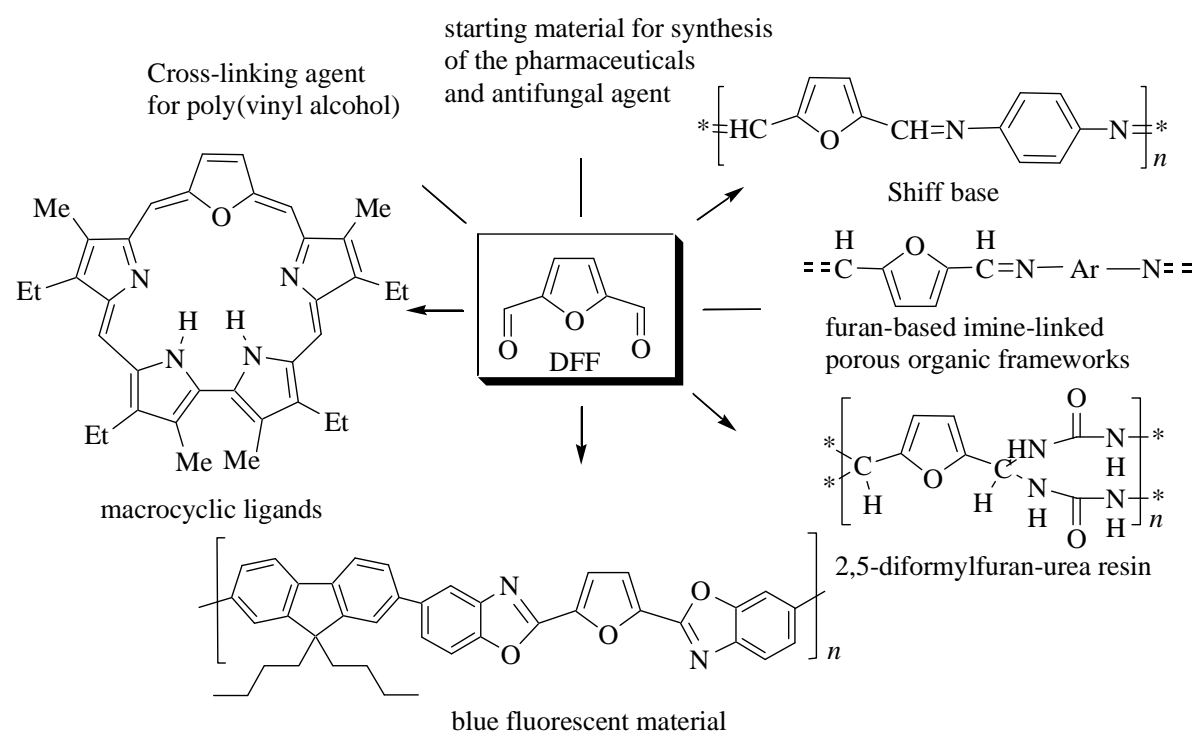

Fig. 6. Applications of DFF.

has the typical chemical properties of an aldehyde. Its applications (Fig. 6) as an intermediate for the synthesis of pharmaceuticals [84], antifungal agent [85], macrocyclic ligand [86,87], and organic conductor [88] have been described. DFF is also used as an important monomer for furan based polymers. For example, Gandini and co-workers [89] described a polymeric Shiff base containing DFF and $p$-phenylenediamine. Amarasekara et al. [90] reported the synthesis and characterization of a DFF-urea resin. Very recently, Xu and coworkers [91] synthesized a new blue-emitting fluorescent material with quantum yield as much as 57\%. Furan-based porous organic frameworks are also synthesized using DFF as the key building blocks [92].

DFF can be synthesized by the selective oxidation of HMF. Conventionally, DFF are synthesized by stoichiometric and electro-oxidation methods [93-95]. The yield of DFF is usually low under catalytic conditions. From the viewpoint of economic and sustainable development, the catalytic oxidation of HMF to DFF with dioxygen is enticing.

In the early 1990s, Sheldon et al. [96] reported the catalytic oxidation of HMF to DFF using titanium silicalite zeolite (TS-1) as catalyst with hydrogen peroxide as oxidant in methanol or water. The yield of DFF was only $25 \%$. They further used chloroperoxidase as catalyst and the selectivity of DFF was 60\%-74\% [97]. In 2008, Amarasekara et al. [98] reported the oxidation of HMF by Mn(III)-salen in a phosphate buffer solution- $\mathrm{CH}_{2} \mathrm{Cl}_{2}$ biphasic solvent system. The yield of DFF was $63 \%-89 \%$ with sodium hypochlorite as oxidant under room temperature.

In 1993, Verdeguer et al. [99] reported the oxidation of HMF catalyzed by $\mathrm{Pt} / \mathrm{C}$. The product distribution depended on the solvent, pH, temperature, oxygen pressure and catalyst. A 19\% yield of DFF was obtained under high temperature and neutral conditions. The $\mathrm{Co} / \mathrm{Mn} / \mathrm{Br}$ catalytic system was also used to catalyze the oxidation of HMF, and $63 \%$ yield of DFF was obtained under $7 \mathrm{MPa}$ air pressure in acetic acid in $2 \mathrm{~h}$ [100]. However, bromine is very corrosive, which limited the application of this catalytic system.
In the late of 1990s, Moreau et al. [101] reported the catalytic oxidation of HMF to DFF with $\mathrm{V}_{2} \mathrm{O}_{5} / \mathrm{TiO}_{2}$ as catalyst and oxygen as oxidant. A 91\% conversion of $\mathrm{HMF}$ and 93\% selectivity for DFF was obtained under 1 MPa oxygen in toluene in 2 h. However, too much catalyst was needed and the mass ratio of catalyst to substrate was as much as $2 / 1$. With $\mathrm{VOPO}_{4} \cdot 2 \mathrm{H}_{2} \mathrm{O}$ (VOP) as catalyst, $84 \%$ conversion of $\mathrm{HMF}$ and $97 \%$ selectivity of DFF was obtained at $150{ }^{\circ} \mathrm{C}$ in DMSO in $6 \mathrm{~h} \mathrm{[102].} \mathrm{Other} \mathrm{met-}$ al modified VOP did not show better activity. In 2009, Navarro et al. [103] studied the aerobic oxidation of HMF with homogeneous pyridine-vanadyl complexes in a homogeneous phase, with $\mathrm{Cu}$ and $\mathrm{V}$ in poly(4-vinylpyridine) crosslinked with $33 \%$ divinylbenzene (PVP) and supported on organofunctionalized SBA-15 mesoporous materials. It was found that pyridine-vanadyl complexes in the polymeric form showed higher performance than those supported on organofunctionalized SBA-15. In 2011, Xu and coworkers [91] reported that 99\% conversion and selectivity can be obtained with a $\mathrm{Cu}\left(\mathrm{NO}_{3}\right)_{2} / \mathrm{VOSO}_{4}$ catalytic system under mild conditions. $\mathrm{VV}$ species was the active species. It was demonstrated that $\mathrm{Cu}\left(\mathrm{NO}_{3}\right)_{2}$ facilitates the generation of $\mathrm{VV}$ species from $\mathrm{VOSO}_{4}$ and a VV/VIV redox cycle was involved. Recently, Liu and coworkers [104] also found that HMF oxidation to DFF proceeds via the redox mechanism involving Vv/VIV redox cycles and the reoxidation of $\mathrm{VIV}^{\mathrm{IV}}$ to $\mathrm{VV}$ by $\mathrm{O}_{2}$ was the rate determining step.

Considering the difficult separation of HMF from the reaction mixture, the in situ oxidation of HMF in the dehydration of carbohydrate would make the separation easier. Halliday et al. [105] reported a one-pot two-step method to synthesize DFF with fructose as the substrate. Fructose was first dehydrated to HMF catalyzed by acidic ion exchange resin. Then, the acidic ion exchange resin was isolated from the reaction mixture and the vanadium-based catalyst was then added to catalyze the oxidation of HMF to DFF. The yield of DFF was $45 \%$ based on fructose at $150{ }^{\circ} \mathrm{C}$ under $0.1 \mathrm{MPa}$. Carlini et al. [102] tried to synthesize DFF from fructose using VOP as catalyst, but no DFF 
Table 1

Representative catalytic conversion of HMF to FDCA catalyzed by different noble metal catalysts.

\begin{tabular}{|c|c|c|c|c|c|c|c|c|}
\hline Catalyst & $\mathrm{S} / \mathrm{C}(n / n)$ & Solvent & Base & $t / \mathrm{h}$ & $\mathrm{T} /{ }^{\circ} \mathrm{C}$ & $P / \mathrm{MPa}$ & Yield (\%) & Ref. \\
\hline $\mathrm{Pt} / \mathrm{Al}_{2} \mathrm{O}_{3}$ & 31 & $\mathrm{H}_{2} \mathrm{O}$ & $\mathrm{pH}=9$ & 6 & 60 & 0.02 & $>90$ & [126] \\
\hline $\mathrm{Au} / \mathrm{TiO}_{2}$ & 308 & $\mathrm{MeOH}$ & $7.5 \mathrm{~mol} \% \mathrm{NaOMe}$ & 3 & 130 & 0.4 & 98 & [129] \\
\hline $\mathrm{Au} / \mathrm{TiO}_{2}$ & 100 & $\mathrm{H}_{2} \mathrm{O}$ & 20 equiv. & 18 & 30 & 2 & 71 & [130] \\
\hline $\mathrm{Au} / \mathrm{CeO}_{2}$ & 640 & $\mathrm{H}_{2} \mathrm{O}$ & 4 equiv. & 5 & 130 & 1 & 96 & [131] \\
\hline $\mathrm{Au} / \mathrm{TiO}_{2}$ & 640 & $\mathrm{H}_{2} \mathrm{O}$ & 4 equiv. & 8 & 130 & 1 & 84 & [131] \\
\hline $\mathrm{Au} / \mathrm{CeO}_{2}$ & 300 & $\mathrm{MeOH}$ & free & 5 & 130 & 1 & 98 & [132] \\
\hline $\mathrm{Au} / \mathrm{TiO}_{2}$ & 300 & $\mathrm{MeOH}$ & free & 24 & 130 & 1 & 96 & {$[132]$} \\
\hline $\mathrm{Au}-\mathrm{Cu} / \mathrm{TiO}_{2}$ & 100 & $\mathrm{H}_{2} \mathrm{O}$ & 4 equiv. & 4 & 110 & 1 & 99 & [133] \\
\hline $\mathrm{Au} / \mathrm{HT}$ & 40 & $\mathrm{H}_{2} \mathrm{O}$ & free & 7 & 95 & flow & $>99$ & {$[134]$} \\
\hline $\mathrm{Ru}(\mathrm{OH})_{x} / \mathrm{MgO} \cdot \mathrm{La}_{2} \mathrm{O}_{3}$ & 20 & $\mathrm{H}_{2} \mathrm{O}$ & free & 6 & 140 & 0.25 & $>95$ & [135] \\
\hline $\mathrm{Ru}(\mathrm{OH})_{x} / \mathrm{HT}$ & 20 & $\mathrm{H}_{2} \mathrm{O}$ & free & 6 & 140 & 0.25 & $>99$ & [136] \\
\hline
\end{tabular}

was found either in water or a water-methyl isobutyl ketone biphasic solvent system. In 2011, Takagaki et al. [106] found that fructose and glucose can be converted to DFF with the combination of HT, Amberlyst-15 and Ru/HT as catalysts. The yields of DFF from fructose and glucose were $49 \%$ and $25 \%$, respectively. Xiang et al. [107] investigated the synthesis of DFF from glucose using the one-pot two-step approach over $\mathrm{CrCl}_{3} \cdot 6 \mathrm{H}_{2} \mathrm{O} / \mathrm{NaBr} / \mathrm{NaVO}_{3} \cdot 2 \mathrm{H}_{2} \mathrm{O}$ catalysts. A DFF yield of $55 \%$ based on glucose was obtained. It was found that $\mathrm{NaBr}$ inhibited the oxidation of $\mathrm{HMF}$, and $\mathrm{NaVO}_{3} \cdot 2 \mathrm{H}_{2} \mathrm{O}$ has a negative impact in the dehydration of glucose. Very recently, Fu and coworkers [108] demonstrated the direct synthesis of DFF from fructose via acid-catalyzed dehydration. Successive aerobic oxidation in the one-pot reaction was successfully catalyzed by a combination of $\mathrm{Fe}_{3} \mathrm{O}_{4}-\mathrm{SBA}-\mathrm{SO}_{3} \mathrm{H}$ and K-OMS-2. Stepwise addition of the catalysts gave 2,5 -DFF in $80 \%$ yield.

\subsection{Catalytic oxidation of HMF to FDCA}

FDCA is used in pharmaceuticals. For example, its diethyl ester has a similar anesthetic effect to cocaine. Calcium 2,5-furandicarboxylate can inhibit the growth of Bacillus magaterium [29]. Besides, FDCA is like terephthalic acid in its conjugated structure and isoelectronic property (Fig. 7). FDCA is also used as the building block for the synthesis of polyesters or copolyesters [109-123]. 1n 2004, it was identified as one of the twelve biomass-derived platform chemicals by the United States Department of Energy (DOE) [124]. Thus the synthesis of FDCA is considered a representative biorefinery process.

FDCA can be produced by the oxidation of HMF by traditional stoichiometric and catalytic methods. The stoichiometric oxidation process usually leads to formation of abundant byproducts of inorganic salts or metal oxide, resulting in low atom utilization. Catalytic aerobic oxidation of HMF to FDCA is more attractive for its high utilization of reactant atoms, and water is the only byproduct. This is a clean, environmentally friendly and sustainable way to synthesize FDCA.

$\mathrm{Co} / \mathrm{Mn} / \mathrm{Br}$ is an efficient catalytic system for the large scale

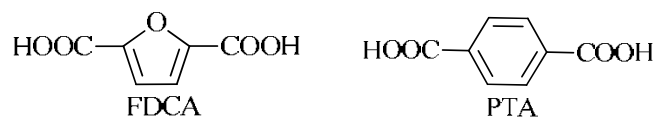

Fig. 7. Molecular structure of FDCA and PTA. production of terephthalic acid. It was introduced by Partenheimer et al. [100] for the aerobic oxidation of HMF to FDCA. After promotion by a co-catalyst, the yield of FDCA reached $61 \%$ at $125^{\circ} \mathrm{C}$ after $3 \mathrm{~h}$ under $7 \mathrm{MPa} \mathrm{O}_{2}$. The selectivity of FDCA and FFCA catalyzed by homogeneous $\mathrm{Co}(\mathrm{OAc})_{2} /$ $\mathrm{Zn}(\mathrm{OAc})_{2} / \mathrm{NaBr}$ was improved in the presence of the HTFA (1 wt $\%$ ) as additive [125]. However, $\mathrm{HBr}$ was generated in the catalytic process, which is corrosive.

So far, reported works on the oxidation of HMF to FDCA are still focused on noble metal catalysts, including Pt, Au, and Ru. Some results are summarized in Table 1. The oxidation of HMF catalyzed by Pt-based catalysts favorably proceeds to FDCA when the reaction was performed under oxygen pressure and a controlled $\mathrm{pH}$ value [126]. Since the 1980s, gold catalysis has been made much progress in a variety of fields $[127,128]$. There have been reports of $\mathrm{Au}$ catalyzed aerobic oxidation of HMF to FDCA.

Taarning et al. [129] reported the oxidation of HMF catalyzed by $\mathrm{Au} / \mathrm{TiO}_{2}$ using methanol as solvent. A stoichiometric ester of FDCA was formed in the presence of catalytic amounts of sodium methoxide (8 mol\%). Gorbanev et al. [130] carried out aerobic oxidation of HMF to FDCA in aqueous media catalyzed by $\mathrm{Au} / \mathrm{TiO}_{2}$ at ambient temperature. The yield of FDCA was $71 \%$ under optimum conditions ( $2 \mathrm{MPa}, n(\mathrm{NaOH}): n(\mathrm{HMF})$ $=20,30^{\circ} \mathrm{C}, 18 \mathrm{~h}$ ).

Casanova et al. [131] carried out aerobic oxidation of HMF in aqueous solution catalyzed by $\mathrm{Au}$ on different supports, including $\mathrm{TiO}_{2}, \mathrm{CeO}_{2}$, active carbon, and $\mathrm{Fe}_{2} \mathrm{O}_{3}$. Among these, $\mathrm{Au} / \mathrm{TiO}_{2}$ and $\mathrm{Au} / \mathrm{CeO}_{2}$ were the better catalysts. Compared with $\mathrm{Au} / \mathrm{TiO}_{2}, \mathrm{Au} / \mathrm{CeO}_{2}$ showed better activity and selectivity. Under the optimized conditions $\left(130^{\circ} \mathrm{C}, 1 \mathrm{MPa} \mathrm{O}_{2}, n(\mathrm{NaOH}): n(\mathrm{HMF})=\right.$ 4 ), the yield of FDCA was as much as $99 \%$. The kinetics of the $\mathrm{Au}$ catalytic reaction showed that the oxidation of hydroxyl group was the rate determining step (Fig. 8). However, the stability and reusability of $\mathrm{Au} / \mathrm{CeO}_{2}$ still remain questions. The deactivation of $\mathrm{Au} / \mathrm{CeO}_{2}$ was not caused by the leaching of $\mathrm{Au}$, but was probably due to the enrichment of organic carbon on the catalyst. A subsequent study demonstrated that nano-scale $\mathrm{CeO}_{2}$ supported $\mathrm{Au}$ can catalyze aerobic oxidation of $\mathrm{HMF}$ to the corresponding ester of FDCA in alcohol in the absence of a base [132]. Under moderate conditions (65-130 ${ }^{\circ} \mathrm{C}, 1 \mathrm{MPa} \mathrm{O}_{2}$ ), as much as $99 \%$ dimethyl furan-2,5-dicarboxylate was obtained. The testing of the stability and recycling of the catalyst 

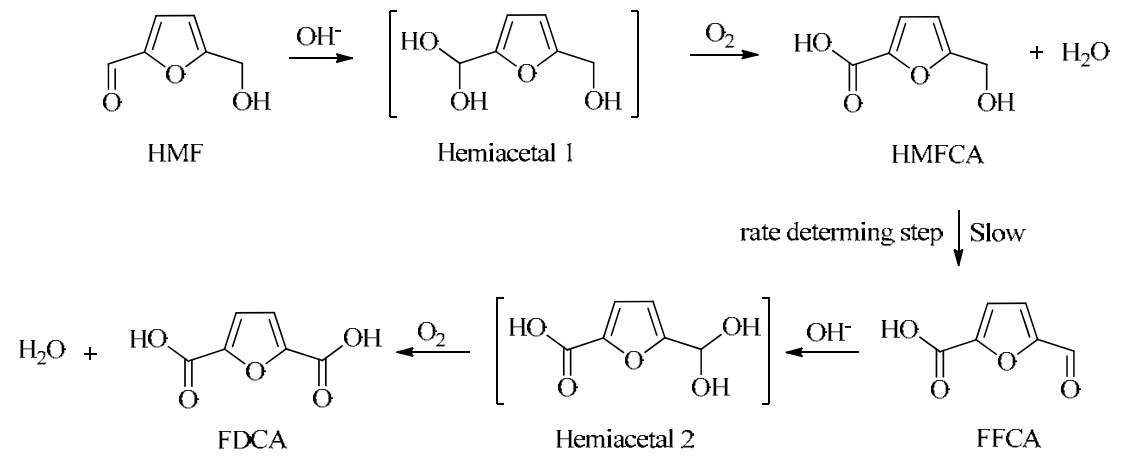

Fig. 8. Reaction pathway for aqueous HMF aerobic oxidation catalyzed by $\mathrm{Au} /$ support [131].

system indicated that deactivation was mainly caused by the enrichment of organic carbon on the catalyst.

Pasini et al. [133] reported a dual metal $\mathrm{Au}-\mathrm{Cu} / \mathrm{TiO}_{2}$ catalyzed aerobic oxidation of HMF. Under optimum conditions, the yield of FDCA reached as much as 99\%. Compared with $\mathrm{Au} / \mathrm{TiO}_{2}$, bimetallic $\mathrm{Au}-\mathrm{Cu} / \mathrm{TiO}_{2}$ is superior in activity and stability, owing to the formation of a AuCu alloy. Gupta et al. [134] carried out aerobic oxidation of HMF to FDCA under atmospheric and base-free aqueous conditions by using alkaline hydrotalcite supported $\mathrm{Au}$ as catalyst. Under the optimized conditions $\left(n(\mathrm{HMF}): n(\right.$ metal $)=40, \mathrm{O}_{2}$ flow rate $=50 \mathrm{ml} / \mathrm{min}, 95{ }^{\circ} \mathrm{C}, 7$ h), 99\% of FDCA was obtained.

Besides $\mathrm{Au}$, the noble metal $\mathrm{Ru}$ is also good at catalyzing the oxidation of alcohol. Gorbanev et al. [135] studied aqueous, base-free aerobic oxidation of HMF to FDCA catalyzed by Ru on different supports, including $\mathrm{TiO}_{2}, \mathrm{Al}_{2} \mathrm{O}_{3}, \mathrm{Fe}_{3} \mathrm{O}_{4}, \mathrm{ZrO}_{2}, \mathrm{CeO}_{2}$ $\mathrm{MgO}, \mathrm{La}_{2} \mathrm{O}_{3}, \mathrm{MgAl}_{2} \mathrm{O}_{4}$, HT, Hydroxyapatite and $\mathrm{MgO} \cdot \mathrm{La}_{2} \mathrm{O}_{3}$. The alkaline $\mathrm{MgO} \cdot \mathrm{La}_{2} \mathrm{O}_{3}$ supported Ru catalyst was preferred, and it gave more than $90 \%$ FDCA under 2.5 bar $\mathrm{O}_{2}$ in $6 \mathrm{~h}$ at $140{ }^{\circ} \mathrm{C}$. $\mathrm{A}$ further study of $\mathrm{Ru}(\mathrm{OH})_{x} / \mathrm{MgO}, \mathrm{Ru}(\mathrm{OH})_{x} / \mathrm{MgAl}_{2} \mathrm{O}_{4}$ and $\mathrm{Ru}(\mathrm{OH})_{x} / \mathrm{HT}$ demonstrated that the alkaline support was partly dissolved under the reaction conditions and this made the solution alkaline, which in turn facilitated HMF conversion to FDCA [136]. The kinetics of the reaction of Ru catalyst system demonstrated that the oxidation of hydroxyl group and aldehyde group are competitive reactions, which is quite different from that of the Au catalyst system (Fig. 9).

To study the activity of different noble metal catalysts under identical conditions, Davis et al. [137] evaluated the aqueous phase oxidation of HMF to FDCA catalyzed by the Pt, Pd, Au catalyst systems. Under the test conditions $\left(22{ }^{\circ} \mathrm{C}, 0.69 \mathrm{MPa} \mathrm{O_{2 }}\right.$ $0.15 \mathrm{~mol} / \mathrm{L} \mathrm{HMF}, 0.3 \mathrm{~mol} / \mathrm{L} \mathrm{NaOH}$ ), Pt/C, Pd/C, Au/C (WGC) (provided by the World Gold Council), $\mathrm{Au} / \mathrm{C}(\mathrm{sol}), \mathrm{Au} / \mathrm{TiO}_{2}$ gave TOFs of $0.08,0.15,5.0,2.3,1.6 \mathrm{~s}^{-1}$, respectively. Under the same conditions, Pt and Pd successfully catalyzed the oxidation of HMFCA to FDCA, but Au did not, implying that the pathway of hydroxyl group oxidation catalyzed by $\mathrm{Pt}$ and $\mathrm{Pd}$ is different from that catalyzed by $\mathrm{Au}$. With the Au catalyst, the oxidation of HMFCA to FDCA required a higher $\mathrm{O}_{2}$ pressure and base concentration. In contrast to the $\mathrm{O}_{2}$ pressure, the concentration of the base exerted a larger influence on the oxidation of HMFCA.

Catalytic aerobic oxidation of in situ generated HMF from fructose dehydration to FDCA was also studied. In 2000, Kroger et al. [138] used both a membrane reactor and batch reactor. Fructose dehydration was catalyzed by acid in the aqueous phase. The in situ generated HMF was quickly extracted to the organic phase MIBK and further oxidized to FDCA. Both reactors were shown to be practical in the direct production of FDCA starting with fructose as feedstock and the yield of FDCA reached 25\%. In 2003, Ribeiro et al. [139] reported the conversion of fructose into FDCA in aqueous media catalyzed by $\mathrm{Co}$ (acac) $)_{2} / \mathrm{SiO}_{2}$, in which the acidic support $\mathrm{SiO}_{2}$ acted as the active center for dehydration, and Co was responsible for oxidation. The conversion of fructose was as high as $72 \%$, and the selectivity for FDCA was as much as $99 \%$ under $160^{\circ} \mathrm{C}, 2 \mathrm{MPa}$ $\mathrm{O}_{2}$ for $65 \mathrm{~min}$.

\section{Polyols}

Polyols are widely used as chemicals and as precursors in the synthesis of fuels and value added compounds. The catalytic conversion of biomass resource to produce important polyols can provide a sustainable and clean route compared with the petroleum-based route.

\subsection{Cellulose to sugar alcohols}

Sugar alcohols, such as sorbitol and mannitol, are consid-<smiles>CC(C)(C)C(=O)c1ccc(C(=O)O)o1</smiles>

Fig. 9. Reaction pathway for aqueous HMF aerobic oxidation catalyzed by Ru/support [136]. 


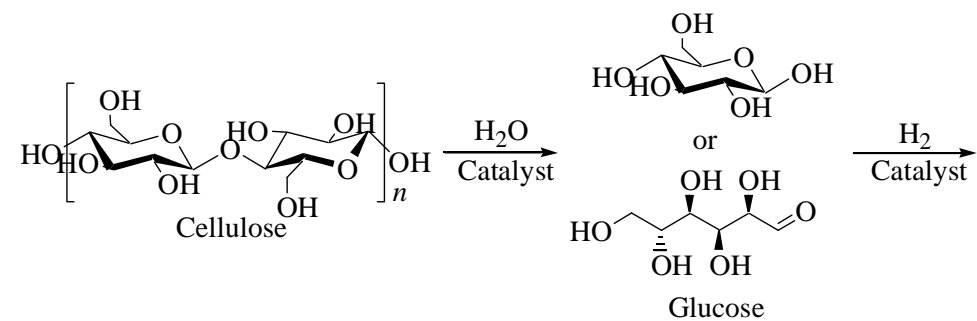<smiles>OC[C@H](O)[C@@H](O)[C@@H](O)[C@H](O)CO</smiles>

Fig. 10. Catalytic conversion of cellulose into sugar alcohols.

ered new bioplatform compounds, which are widely used in gas fuels $\left(\mathrm{H}_{2}\right.$, synthesis gas), liquid alkanes, liquid fuels and oxygenates and for producing chemicals like ethylene EG and PG. Cellulose is composed of D-glucose units connected by $\beta$-14-glycosidic bonds. The structure is similar to sugar alcohols, therefore, the direct conversion of cellulose to sugar alcohols would have high atom economy and high energy efficiency.

The catalytic conversion of cellulose to sugar alcohols is a two-step process, which includes the hydrolysis of cellulose to sugar and subsequently hydrogenation of the sugar to the sugar alcohol (Fig. 10). Fukuoka and coworkers [140] first reported that cellulose can be efficiently converted into sugar alcohols over supported metal catalysts, and 31\% yield of sugar alcohols was obtained over $\mathrm{Pt} / \mathrm{Al}_{2} \mathrm{O}_{3}$ catalysts in $24 \mathrm{~h}$ at $190{ }^{\circ} \mathrm{C}$ and 5 $\mathrm{MPa} \mathrm{H}_{2}$. They suggested that cellulose first underwent a hydrolysis reaction to generate glucose over the acid sites of the support, using $\mathrm{H}_{2}$ derived in situ. Then, hydrogenation of the generated glucose was conducted on the Pt metal catalyst. Liu and coworkers [141,142] have also been interested in cellulose conversion. They first studied cellobiose as a model cellulose to study the cleavage of glycosidic bonds. The sorbitol yield can be $100 \%$ over a Ru/C catalyst at $120{ }^{\circ} \mathrm{C}$ and $4 \mathrm{MPa}$. The result inspired them to the further study of the direct conversion of cellulose to sugar alcohols, and they obtained 30\% and $10 \%$ yields of sorbitol and mannitol, respectively, under $6 \mathrm{MPa}$ and $245^{\circ} \mathrm{C}$ over $\mathrm{Ru} / \mathrm{C}$. They proposed that the hot water was the key factor for cellulose conversion, as the acid sites that promoted the hydrolysis of cellulose were reversibly formed in situ from hot water, which can generate $\mathrm{H}^{+}$ions above $200^{\circ} \mathrm{C}$.

Wang and coworkers [143] have used an efficient Ru/CNT catalyst to study the effect of the crystallinity of the cellulose on the yield of sorbitol, and $36 \%$ and $69 \%$ of sorbitol yield were obtained with $85 \%$ and $33 \%$ crystallinity, respectively. Sels and coworkers [144] considered that solid cellulose substrates cannot easily diffuse into conventional solid catalysts. Therefore, they developed a kind of catalyst using carbon nanofibers grown on $\gamma$ - $\mathrm{Al}_{2} \mathrm{O}_{3}$-supported $\mathrm{Ni}$, which gave $50.3 \%$ sorbitol yield. Zhang and coworkers [145] developed an efficient bifunctional nickel phosphide catalyst for the conversion of cellulose. The sorbitol yield achieved $48.4 \%$ at $225^{\circ} \mathrm{C}$ and $6 \mathrm{MPa}$ $\mathrm{H}_{2}$. The excess of $\mathrm{P}$ provided the acidity and the $\mathrm{Ni}_{2} \mathrm{P}$ provided the metallic sites. Sles and coworkers [146] used water-soluble heteropoly acids and a $\mathrm{Ru} / \mathrm{C}$ catalyst to rapidly and selectively transform cellulose to sugar alcohols. The conversion of ball-milled cellulose was $100 \%$ with $85 \%$ yield of sugar alcohol at $190{ }^{\circ} \mathrm{C}$ and 9.5 MPa H . Palkovits et al. [147] have also shown that heteropoly acids combined with supported Ru catalysts can directly convert cellulose to sugar alcohols with a yield of $81 \%$ and above $90 \%$ carbon efficiency. Some representative results are summarized in Table 2.

\subsection{Polyols to EG and 1,2-PG}

EG and 1,2-PG are widely used for agricultural adjuvants, liquid fuels, pharmaceuticals, and emulsifiers, surface active agents, dehumidifying agents, antifreeze agents, lubricants and solvents. Furthermore, EG and 1,2-PG are important raw materials for the synthesis of polyester fibers and resins, like poly(ethylene terephthalate) (PET) and poly(ethylene naphthalate) (PEN). In addition, 1,2-PG is also used for the synthesis of lactic acid, which is the key intermediate for the production of biodegradable polymers (such as polylactic acid). Currently, the production of these diols is from petroleum feedstocks by the hydration of propylene oxide or ethylene oxide. The catalytic conversion of biomass to EG and 1,2-PG has attracted con-

\section{Table 2}

Recent reports on the catalytic conversion of cellulose to sugar alcohols.

\begin{tabular}{lccccc}
\hline Catalyst & $\begin{array}{c}\text { Pressure } \\
(\mathrm{MPa})\end{array}$ & $\mathrm{T} /{ }^{\circ} \mathrm{C}$ & $\begin{array}{c}\text { Time } \\
(\mathrm{h})\end{array}$ & Yield (\%) & Ref. \\
\hline $\mathrm{Pt} / \gamma-\mathrm{Al}_{2} \mathrm{O}_{3}$ & $5(\mathrm{rt})$ & 190 & 24 & Sorbitol (25) Mannitol (6) & {$[140]$} \\
$\mathrm{Ru} / \mathrm{C}$ & 6 & 245 & 0.5 Sorbitol(34.6) Mannitol(11.4) & {$[142]$} \\
$\mathrm{Ru} / \mathrm{CNT}$ & 5 & 185 & 24 & Sorbitol (69) Mannitol (4) & {$[143]$} \\
$\mathrm{Ni} / \mathrm{CNF}$ & 6 & 230 & 4 & Sorbitol (50.3) Mannitol (6.2) & {$[144]$} \\
$\mathrm{Ni} 2 \mathrm{P} / \mathrm{AC}$ & $6(\mathrm{rt})$ & 225 & 1.5 & Sorbitol (48.4) Mannitol( 4.7) & {$[145]$} \\
$\mathrm{Ru} / \mathrm{C}+\mathrm{HPA}$ & 9.5 & 190 & 1 & Sugar alcohols (85) & {$[146]$} \\
$\mathrm{Ru} / \mathrm{C}+\mathrm{HPA}$ & $5(\mathrm{rt})$ & 160 & 7 & Sugar alcohols (81) & {$[147]$} \\
\hline
\end{tabular}

Table 3

Representative reports on the catalytic conversion of glycerol to EG and 1,2-PG

\begin{tabular}{|c|c|c|c|c|c|}
\hline Catalyst & Conditions & $\begin{array}{c}\text { Conv. } \\
(\%)\end{array}$ & $\begin{array}{c}\text { EG Sel } \\
(\%)\end{array}$ & $\begin{array}{l}\text { 1,2-PG } \\
\text { Sel.(\%) }\end{array}$ & Ref. \\
\hline $\mathrm{Ru} / \mathrm{C}+\mathrm{A} 15$ & $120^{\circ} \mathrm{C}, 8 \mathrm{MPa}, 10 \mathrm{~h}$ & 79.3 & 6.8 & 74.9 & [148] \\
\hline $\mathrm{u} / \mathrm{C}+\mathrm{N}$ & $180^{\circ} \mathrm{C}, 6 \mathrm{MPa}, 8 \mathrm{~h}$ & 44.6 & 29.1 & 60.9 & 149] \\
\hline $\mathrm{Ru} / \mathrm{CsPW}$ & $180^{\circ} \mathrm{C}, 0.5 \mathrm{MPa}, 10 \mathrm{~h}$ & 21.0 & 0 & 96.0 & 50] \\
\hline $\mathrm{Ru} / \mathrm{be}$ & $150^{\circ} \mathrm{C}, 0$ & 69.8 & 9.9 & 80.6 & 51] \\
\hline $\mathrm{Ru}$ & $160^{\circ}$ & 38.9 & 2.0 & 56.2 & 152 \\
\hline & 22 & 92.1 & 3.9 & 93 & 153 \\
\hline & & 19.6 & 0 & 34.6 & 154] \\
\hline & 18 & 70.7 & 86.5 & 9.2 & [155] \\
\hline & $180^{\circ} \mathrm{C}$, & 100 & 55 & 43 & [156] \\
\hline & $200^{\circ}$ & 90.4 & 10.7 & 65.7 & [157] \\
\hline $\mathrm{Ni} / \mathrm{l}$ & $200^{\circ} \mathrm{C}$ & 94.5 & 11.1 & 72.1 & [158] \\
\hline Cop & 2 & 54.8 & - & 85 & 59] \\
\hline & & 73.4 & 3.6 & 94.3 & 60 \\
\hline & & 19 & - & 100 & 0 \\
\hline & & 22.5 & 1.3 & 83.6 & {$[162]$} \\
\hline $\mathrm{Ag} / \mathrm{Al}_{2} \mathrm{O}_{3}$ & $220^{\circ} \mathrm{C}, 1.5 \mathrm{MPa}, 10 \mathrm{~h}$ & 46 & 2 & 96 & [163] \\
\hline
\end{tabular}


(a)

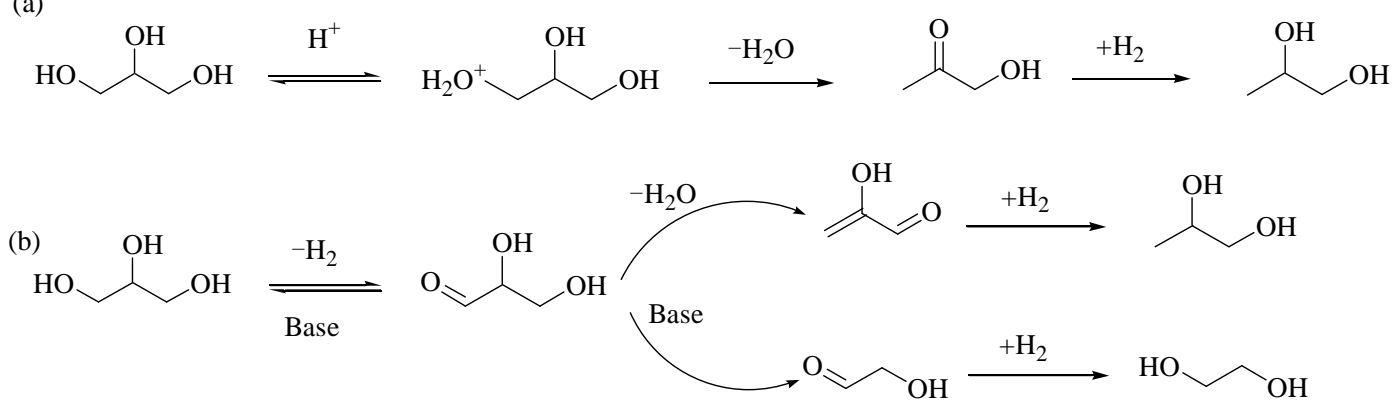

Fig. 11. Reaction route for the catalytic conversion of glycerol to EG and 1,2-PG [147,148,152,173].

siderable interests and several routes from glycerol, sugar alcohol or cellulose have been developed.

\subsubsection{From glycerol}

Glycerol has been prioritized as one of twelve biomass-derived building blocks by the DOE [124]. The swift development of biodiesel has resulted in large amounts of glycerol byproduct. The low price and wide availability have made glycerol a potential feedstock for the production of valuable chemicals and various utilization have been developed. The catalytic hydrogenolysis of glycerol is one method, and many efficient catalyst systems are available for the conversion of glycerol to 1,2-PG and EG. Table 3 summarizes recent representative results.

Due to their high activity, a series of noble metals $(\mathrm{Ru}, \mathrm{Rh}$, Pt, Pd) supported on different supports, such as active carbon [148, 164-166], $\mathrm{SiO}_{2}$ [154], $\mathrm{CaO}$ [155], Clay [167], $\mathrm{TiO}_{2}$ [151, $168,169], \mathrm{ZrO}_{2}[152,170], \mathrm{Al}_{2} \mathrm{O}_{3}$ [171], $\mathrm{Fe}_{2} \mathrm{O}_{3}$ [172], were prepared and studied in the hydrogenolysis of glycerol. Some results are shown in Table 3. Tomishige and coworkers [148] and Lingaiah and coworkers [149] studied a Ru/C catalyst for the hydrogenolysis reaction and found that the addition of Amberlyst resin (e.g. Amberlyst 70 cationic exchange resin) or solid acid (e.g. $\mathrm{Nb}_{2} \mathrm{O}_{5}$ ) greatly enhanced the catalyst performance. An acid catalyzed mechanism was proposed in which the reaction proceeds by the dehydration of glycerol to acetol over acid sites and then hydrogenation to 1,2-PG on the metal catalyst (Fig. 11(a)). Based on this acid-catalyzed mechanism, bifunctional metal-acid catalysts were used for the hydrogenolysis of glycerol. For example, a heteropoly salt of cesium phosphorus tungsten (CsPW) supporting Ru was used by Kozhevnikov and coworkers [150]. The selectivity of 1,2-PG obtained was above $90 \%$ over these catalysts.

In addition to the acid catalyzed mechanism, the alkaline effect on glycerol hydrogenolysis has also been studied. Maris and coworkers [165] used $\mathrm{NaOH}$ or $\mathrm{CaO}$ as the basic additives during testing of the catalytic performance of $\mathrm{Ru} / \mathrm{C}$ and $\mathrm{Pt} / \mathrm{C}$ in glycerol hydrogenolysis. The results showed that the additives increased the reaction rate. Chen and coworkers [173] reported that glycerol was hydrogenolyzed to 1,2-PG with high selectivity and high conversion over a $\mathrm{Ru} / \mathrm{TiO}_{2}$ catalyst in basic aqueous solution. Hou and coworkers [153,174] have developed a solid-base supported catalyst for glycerol hydrogenolysis. A $93 \%$ selectivity for 1,2-PG with $92.1 \%$ glycerol conver- sion over Pt/HT was obtained. From these studies, a base-catalyzed mechanism has been proposed, which is shown in Fig. 11(b). Glycerol is first dehydrogenated to glyceraldehyde on the metal catalyst with the promotion of the base. 1,2-PG was formed by the base catalyzed dehydration of glyceraldehyde and subsequent hydrogenation, while EG was generated by the retro-aldol reaction with subsequent hydrogenation. Although the noble metal based catalysts are highly active, they are expensive, and moreover, some of these catalysts promote the excessive cleavage of $\mathrm{C}-\mathrm{C}$ bonds, resulting in low selectivity to the desired products.

Non-noble metal catalysts have recently also been reported for glycerol hydrogenolysis based on both the acid and alkaline catalyzed mechanisms. Nickel is a non-noble metal, and it has excellent hydrogenation ability. Therefore, Ni-based catalysts for glycerol hydrogenolysis have developed, including Raney $\mathrm{Ni}$ [156], Ni/SBA-15 [175] and $\mathrm{Ni}_{2} \mathrm{P} / \mathrm{SiO}_{2}$ [176]. Xu and coworkers $[157,158,177]$ have recently reported two kinds of Ni-based bifunctional catalysts, $\mathrm{Ni} / \mathrm{AC}$ catalyst and $\mathrm{Ni} / \mathrm{NaX}$ catalyst, which were efficient in glycerol hydrogenolysis. The Ni/AC catalysts were prepared by a novel procedure via impregnation, carbothermal reduction and $\mathrm{KBH}_{4}$-treatment. Through this procedure, the acidity (and activity) of the catalyst was improved as compared with other preparation methods. $\mathrm{Ni} / \mathrm{NaX}$ is another efficient catalyts for glycerol hydrogenolysis and a selectivity for 1,2-PG was as much as $80.4 \%$ with $86.6 \%$ glycerol conversion. These two catalysts for glycerol hydrogenolysis worked by the acid catalyzed mechanism.

$\mathrm{Cu}$-based catalysts are another series of non-noble metal catalysts, and many catalysts have been reported with $\mathrm{Cu}$ as the active metal $\left(\mathrm{Cu}-\mathrm{Cr}[159,178], \mathrm{Cu} / \mathrm{SiO}_{2}[160]\right.$ and $\mathrm{Cu}-\mathrm{Zn}[162$, $179,180]$ ) for the hydrogenolysis of glycerol. These Cu-based catalysts displayed excellent selectivity to 1,2-PG due to the selective cleavage of $\mathrm{C}-\mathrm{O}$ bonds over $\mathrm{C}-\mathrm{C}$ bonds. Zhang and coworkers [163] used $\mathrm{Ag} / \mathrm{Al}_{2} \mathrm{O}_{3}$ to catalyze the glycerol conversion and about $46 \mathrm{~mol} \%$ conversion and $96 \mathrm{~mol} \%$ 1,2-PG selec-

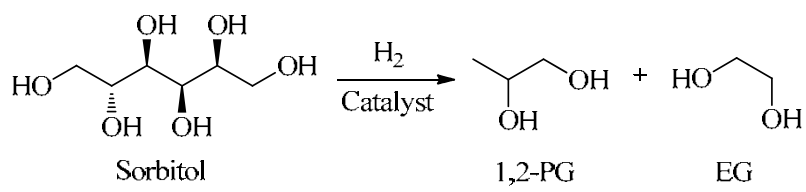

Fig. 12. Catalytic conversion of sorbitol to 1,2-PG and EG. (Sorbitol as representative feedstock). 


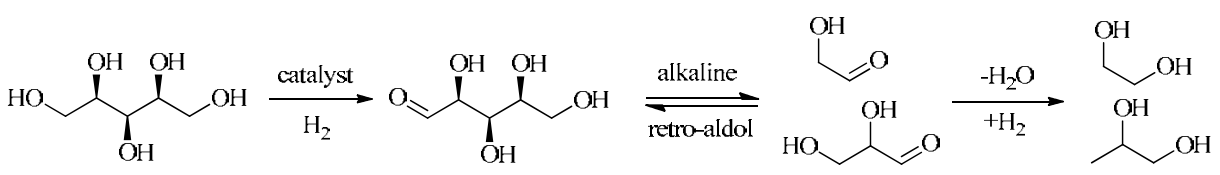

Fig. 13. Proposed route for the hydrogenolysis of sugar alcohol to glycols [185].

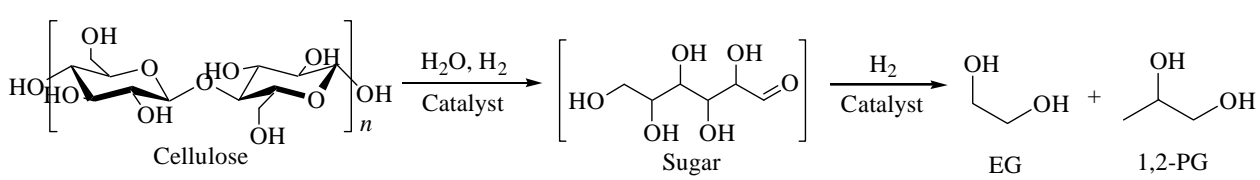

Fig. 14. Catalytic conversion of cellulose into EG and 1,2-PG.

tivity were achieved at $220^{\circ} \mathrm{C}$ and $1.5 \mathrm{MPa}$ initial $\mathrm{H}_{2}$ pressure. The performance is similar to $\mathrm{Cu}$-based catalysts, but $\mathrm{Ag} / \mathrm{Al}_{2} \mathrm{O}_{3}$ needs no preproduction and does not need a high hydrogen pressure. The mechanisms over these $\mathrm{Cu}$ and Ag-based catalysts are similar to the acid and alkaline catalyzed mechanisms.

\subsubsection{From sugar alcohols}

Sugar alcohols are also important sources for producing EG and 1,2-PG (Fig. 12). The most studied sugar alcohols are sorbitol and xylitol. As in the current studies of sugar alcohol hydrogenolysis, Ni or Ru-based catalysts were widely explored, such as $\mathrm{Ni} /$ kieselguhr $\left(\mathrm{SiO}_{2}\right)$ [181], $\mathrm{Ni} / \mathrm{Al}_{2} \mathrm{O}_{3}$ [182], Ni-Re/C [183], Ni-Pt/NaY [184], Ru/C [185] and Ru/nanofibers [186]. In addition, alkali additives were needed to give the basic environment for $\mathrm{C}-\mathrm{C}$ bond cleavage. It has been reported that xylitol and sorbitol can be converted to EG and 1,2-PG using Ni or $\mathrm{Ru}$ based catalysts in the presence of $\mathrm{CaO}$ or $\mathrm{Ca}(\mathrm{OH})_{2}[184,186]$. The more basic $\mathrm{NaOCH}_{3}$ and $\mathrm{KOH}$ have also been used to promote the hydrogenolysis of xylitol and sorbitol [182,183]. Liu and coworkers [185] reported that increasing the $\mathrm{pH}$ value in the aqueous solution from 7 to 12.3 increased the combined selectivity of EG and 1,2-PG. However, further increasing $\mathrm{pH}$ value to 13 or above by using $\mathrm{KOH}$ or $\mathrm{NaOH}$ led to complicated products due to the rapid reactions of xylitol with $\mathrm{OH}^{-}$in the solutions. It has been proposed that the hydrogenolysis of polyols generally involves two key steps: first, the dehydrogenation of polyols to carbonyl intermediates on metal catalysts, and then, the subsequent $\mathrm{C}-\mathrm{C}$ bond cleavage of the intermediates in the basic media, most likely via the retro-aldol condensation [185] (Fig. 13). Competitive reactions with the bases decide the final selectivities of the glycols. The alkali has an important promoting effect, but an alkali reaction media can cause corrosion of the equipment, and also cause environmental problems. Therefore, developing the base-free catalyzed conversion of sugar alcohols to 1,2-PG and EG is of interest.

\subsubsection{From cellulose}

As the most abundant biomass, the direct conversion of cellulose to EG and 1,2-PG is a promising alternative route (Fig. 14). So far, the only efficient reported catalyst system for this reaction is the tungsten-based catalyst developed by Zhang and coworkers [187-191] and Liu and coworkers [192]. Zhang and coworkers first reported that a high yield of EG (around 60\%) can be obtained from cellulose over a $\mathrm{Ni}-\mathrm{W}_{2} \mathrm{C} / \mathrm{AC}$ catalyst [187,
188]. This is a promising substitute for the precious metal catalyst in cellulose conversion. Based on these results, they subsequently developed tungsten-containing catalysts, including 3D mesoporous carbon supported tungsten carbide (EG selectivity, 72.9\%) [189], SBA-15 supported nickel-tungsten bimetallic catalysts (EG yield, 75.4\%) [190] and tungsten phosphide catalyst (EG yield, 46\%). Liu and coworkers [192] have further developed the tungsten trioxide promoted selective conversion of cellulose into 1,2-PG and EG on a ruthenium catalyst. They found that $\mathrm{WO}_{3}$ crystallites efficiently promoted the hydrolysis of cellulose to sugar intermediates and also promoted the selective cleavage of the $\mathrm{C}-\mathrm{C}$ bonds. Recently, Zhang and coworkers [193-195] extended the feedstock from microcrystalline cellulose to lignocelluloses (such as corn stalk, birch and other woody biomass) and Jerusalem Artichoke Tuber. These studies provide a better understanding of the biomass transformation.

\subsection{Catalytic conversion of glycerol to 1,3-PG}

1,3-PG is an important diol for synthesizing highly valuable polyesters, especially poly(trimethylene terephthalate) (PTT), which has excellent chemical resistance, light stability, elastic recovery and dyeability. 1,3-PG is generally produced from the hydroformylation of ethylene oxide to 3-hydroxylpropionaldehyde followed by hydrogenation, or from the hydration of acrolein and subsequent hydrogenation. Recently, the direct production of 1,3-PG from a biomass-derived feedstock has received much attention, and fermentation methods have been widely used for glycerol conversion. However, the biological process has a low metabolic efficiency and poor compatibility. Therefore, a chemical catalytic process to produce 1,3-PG from

Table 4

Summary of the production of 1,3-PG from glycerol hydrogenolysis.

\begin{tabular}{lccccc}
\hline Catalyst & Solvent & Conditions & $\begin{array}{r}\text { Sel. } \\
(\%)\end{array}$ & $\begin{array}{c}\text { Yield } \\
(\%)\end{array}$ & Ref. \\
\hline $\mathrm{Pt} / \mathrm{WO}_{3} / \mathrm{ZrO}_{2}$ & $\mathrm{DMI}$ & $170{ }^{\circ} \mathrm{C}, 8 \mathrm{MPa}$ & - & 24.2 & {$[196]$} \\
$\mathrm{Pt} / \mathrm{WO}_{3} / \mathrm{ZrO}_{2}$ & $\mathrm{DMI}-\mathrm{H}_{2} \mathrm{O}$ & $170{ }^{\circ} \mathrm{C}, 5.5 \mathrm{MPa}$ & 34.9 & 11.0 & {$[197]$} \\
$\mathrm{Pt} / \mathrm{WO}_{3} / \mathrm{ZrO}_{2}$ & $\mathrm{H}_{2} \mathrm{O}$ & $130{ }^{\circ} \mathrm{C}, 4 \mathrm{MPa}$ & 45.6 & 32.0 & {$[198]$} \\
$\mathrm{Pt} / \mathrm{WO}_{3} / \mathrm{TiO}_{2} / \mathrm{SiO}_{2}$ & $\mathrm{H}_{2} \mathrm{O}$ & $180^{\circ} \mathrm{C}, 5.5 \mathrm{MPa}$ & 50.5 & 7.7 & {$[199]$} \\
$\mathrm{Pt}-\mathrm{sulfated} \mathrm{ZrO}_{2}$ & $\mathrm{DMI}$ & $170{ }^{\circ} \mathrm{C}, 7.3 \mathrm{MPa}$ & 83.6 & 55.6 & {$[200]$} \\
$\mathrm{Ir}-\mathrm{ReO}_{x} / \mathrm{SiO}_{2}$ & $\mathrm{H}_{2} \mathrm{O}+\mathrm{H}_{2} \mathrm{SO}_{4}$ & $120^{\circ} \mathrm{C}, 8 \mathrm{MPa}$ & 49.0 & 38.0 & {$[201]$} \\
$\mathrm{Cu}-\mathrm{H}_{4} \mathrm{SiW}_{12} \mathrm{O}_{40} / \mathrm{SiO}_{2}$ & - & $210^{\circ} \mathrm{C}, 0.54 \mathrm{MPa}$ & 32.1 & 26.8 & {$[202]$} \\
$\mathrm{Pt}-\mathrm{H}_{4} \mathrm{SiW}_{12} \mathrm{O}_{40} / \mathrm{SiO}_{2}$ & $\mathrm{H}_{2} \mathrm{O}$ & $200^{\circ} \mathrm{C}, 5 \mathrm{MPa}$ & 27.2 & 24.1 & {$[203]$} \\
\hline
\end{tabular}

DMI stands for 1,3-dimethyl-2-imidazolidinone. 


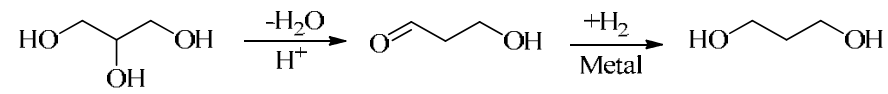

Fig. 15. Catalytic conversion of glycerol to $1,3-\mathrm{PG}$.

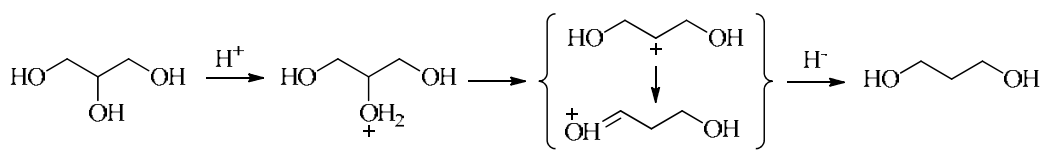

Fig. 16. Proposed route for glycerol to 1,3-PG via the ionic mechanism [198].

glycerol would be more applicable and cleaner. In the early days, homogeneous catalysts were used to produce 1,3-PG from glycerol. Due to separation problems, developing efficient heterogeneous catalyst systems for the catalytic hydrogenolysis of glycerol into 1,3-PG is desirable. The production of 1,3-PG over a heterogeneous catalyst is more challenging than that of 1,2-PG. There are several efficient catalyst systems. Some representative ones are listed in Table 4.

The $\mathrm{Pt} / \mathrm{WO}_{3} / \mathrm{ZrO}_{2}$ catalyst was studied by several groups. It is an efficient catalyst in the catalytic conversion of glycerol to 1,3-PG, and the best yield of 1,3-PG over this catalyst was 32\% [198]. Sasaki and coworkers [196] showed that Pt was the most effective active among the screened noble metal catalysts and found that the sequential impregnation process was important as it provided the active sites for hydrogenolysis of glycerol. Based on this catalyst system, Ding and coworkers [199] developed a bifunctional catalyst $\mathrm{Pt} / \mathrm{WO}_{3} / \mathrm{TiO}_{2}$ on silica, and found that the existence of $\mathrm{TiO}_{2}$ species improved the dispersion of the Pt metal, and the $\mathrm{WO}_{3}$ species increased the acidity. Lee and coworkers [200] have developed another Pt-based catalyst by using sulfated zirconia to support the Pt metal. They found that $\mathrm{Pt}$ and sulfate ions were stabilized in the more active tetragonal zirconia phase. The yield of 1,3-PG was as high as $55.6 \%$. Another efficient system is the Ir-Re catalyst system. Tomishige and coworkers [201,204] prepared a $\mathrm{ReO}_{x}$ modified $\mathrm{Ir} / \mathrm{SiO}_{2}$ catalyst. $38 \%$ yield of $1,3-\mathrm{PG}$ was obtained with $81 \%$ conversion of glycerol. In addition, the combination of a heteropoly acid with a metal catalyst was applied to the conversion of glycerol to 1,3-PG, such as $\mathrm{Cu}-\mathrm{H}_{4} \mathrm{SiW}_{12} \mathrm{O}_{40} / \mathrm{SiO}_{2}$ [202], $\mathrm{Pt}-\mathrm{H}_{4} \mathrm{SiW}_{12} \mathrm{O}_{40} \mathrm{SiO}_{2}$ [203] and $\mathrm{Pt} / \mathrm{H}_{3} \mathrm{PW}_{12} \mathrm{O}_{40} / \mathrm{ZrO}_{2}$ [205]. The heteropoly acid provides the appropriate acid sites and acid strength, and a supported heteropoly acid avoids a separation process and reduce the use of corrosive liquids.

Many studies have revealed that an aqueous phase favored the formation of 1,2-PG, while a polar aprotic solvent favored 1,3-PG generation. Therefore, organic solvents (e.g. DMF) were used to produce 1,3-PG [196,197,200]. However, the use of polar aprotic organic solvents is restricted as they are not environmentally benign. Therefore, methods to produce 1,3-PG from glycerol without utilizing these organic solvents have attracted attention. A solvent-free system was developed by Zhu and coworkers [202] and 32.1\% selectivity for 1,3-PG was obtained in the vapor phase reaction. However, the vaporization of glycerol at elevated temperatures in the presence of copper metal readily led to byproducts. Water is a cheap green solvent, and synergy is possible if water is selected as the reaction medium. Another important consideration is the high water content of the crude glycerol from biodiesel manufacture. Ding and coworkers [197,199] demonstrated selective dehydroxylation of glycerol to 1,3-PG conducted in water solutions. Their results showed that water is the preferred solvent for this catalyst.

The current understanding of the glycerol to 1,3-PG conversion is that it is the route of the removal of the second hydroxyl group of glycerol and then hydrogenation to 1,3-PG (see Fig. 15). The key intermediate in 1,3-PG from glycerol hydrogenolysis is 3-hydroxypropanal, which indicated that the removal of the second hydroxyl group of glycerol is the required reaction. This reaction can be greatly promoted by an acid catalyst. Therefore, the presence of acid sites is important. Acid additives (e.g. $\mathrm{H}_{2} \mathrm{SO}_{4}$ ), supported hetropoly acids, supported acidic oxides or acidic support are used in the reaction to improve the yield of 1,3-PG.

Qin and coworkers [198] have proposed that the deoxygenation of glycerol occurs via an ionic mechanism over $\mathrm{Pt} / \mathrm{WO}_{3} / \mathrm{ZrO}_{2}$ (Fig. 16). In this mechanism, protons and hydride ions are generated from $\mathrm{H}_{2}$ by heterolytic cleavage of hydrogen molecules on the catalyst. The $\mathrm{H}^{+}$reacts with glycerol, which is followed by the reaction with $\mathrm{H}^{-}$. The high selectivity of 1,3-PG was attributed to the preferential dehydration of the secondary hydroxyl group.

Tomishige and coworkers [201] proposed a reaction mechanism with a Ir-ReOx catalyst (Fig. 17). One of the terminal hydroxyl groups of glycerol first adsorbs on $\mathrm{ReO}_{\mathrm{x}}$ surface to form 2,3-dihydroxypropoxide. Then $\mathrm{H}$ activated by Ir metal attacks the secondary carbon to give 3-hydroxypropoxide. Then the hydrolysis reaction forms 1,3-PG. The growth of oxidized metal clusters was sufficient to give the preferred formation of the terminal alkoxide, which is the key for a high selectivity of 1,3-PG.

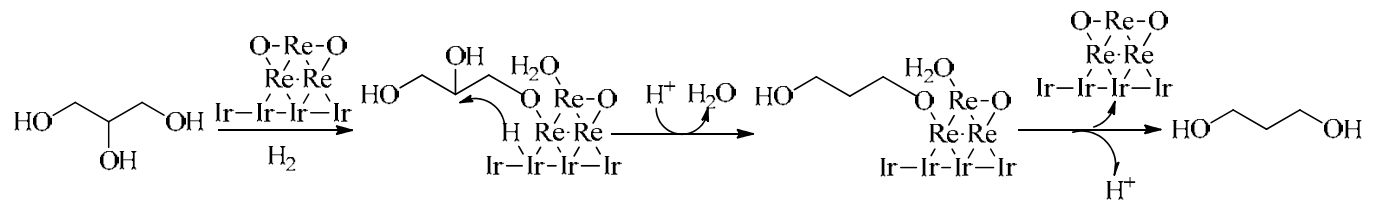

Fig. 17. Proposed route for glycerol to $1,3-\mathrm{PG}$ over a Ir-ReOx/SiO2 catalyst [201]. 


\section{Conclusions and outlooks}

Chemicals from biomass have attracted increasing research interest because of diminishing fossil fuel reserves and environmental problems. At present, as compared to the large scale petroleum industries, it is less economical to make chemicals from biomass because fossil oils are still available in large quantities. However, in the long term, the production of chemicals from biomass is the most economical and renewable alternative for a sustainable society. Much effort have been made in fundamental research, but there are still issues to be solved before biomass can be used. The utilization of cellulose as the feedstock for the synthesis of chemicals is promising as it is the most abundant component in biomass.

For furan derivatives, the pilot scale production and effective separation of HMF in a green and low energy consuming process needs to be further studied [36,206]. Although the synthesis of furan-based polymers has been started, comparisons of the similarities and differences of the chemical and physical properties of biomass-based polymers and petroleum-based polymers are few. The application potential of furan-based polymers is the impetus for the catalytic conversion of biomass to HMF platform molecules.

Polyols can be directly used as chemicals and also as the precursors for the synthesis of resins, value-added compounds and fuels. The versatile uses of polyols make a biomass-derived route for them obviously useful, especially a catalytic conversion process. This process can provide a sustainable production of polyols from biomass-derived feedstocks and also open the way for the utilization of biomass.

\section{References}

[1] Gallezot P. Chem Soc Rev, 2012, 41: 1538

[2] Zhou C H, Xia X, Lin C X, Tong D S, Beltramini J. Chem Soc Rev, 2011, 40: 5588

[3] Corma A, Iborra S, Velty A. Chem Rev, 2007, 107: 2411

[4] Serrano-Ruiz J C, Luque R, Sepulveda-Escribano A. Chem Soc Rev, 2011, 40: 5266

[5] Song Q Wang F, Xu J. Chem Commun, 2012, 48: 7019

[6] Che P H, Lu F, Zhang J J, Huang Y Z, Nie X, Gao J, Xu J. Bioresour Technol, 2012, 119: 433

[7] Ma H, Nie X, Cai J Y, Chen C, Gao J, Miao H, Xu J. Sci China Chem, 2010, 53: 1497

[8] Du Z T, Ma J P, Wang F, Liu J X, Xu J. Green Chem, 2011, 13: 554

[9] Wang F, Xu J, Dubois J L, Ueda W. ChemSusChem, 2010, 3: 1383

[10] Liu J X, Du Z T, Yang Y L, Lu T L, Lu F, Xu J. ChemSusChem, 2012, 5: 2151

[11] Shuttleworth P, Budarin V, Gronnow M, Clark J H, Luque R. J Nat Gas Chem, 2012, 21: 270

[12] Luque R, Pineda A, Colmenares J C, Campelo J M, Romero A A, Serrano-Ruiz J C, Cabeza L F, Cot-Gores J. J Nat Gas Chem, 2012, 21: 246

[13] Yang P F, Kobayashi H, Fukuoka A. Chin J Catal (催化学报), 2011, 32: 716

[14] Zhang Y M, Degirmenci V, Li C, Hensen E J M. ChemSusChem, 2011, 4: 59

[15] Zhang J, Wu S B, Li B, Zhang H D. ChemCatChem, 2012, 4: 1230

[16] Roman-Leshkov Y, Barrett C J, Liu Z Y, Dumesic J A. Nature, 2007,
447: 982

[17] Hu L, Sun Y, Lin L. Prog Chem (胡磊, 孙勇, 林鹿. 化学进展), 2011, 23: 2079

[18] Rosatella A A, Simeonov S P, Frade R F M, Afonso C A M. Green Chem, 2011, 13: 754

[19] Tong X L, Ma Y, Li Y D. Appl Catal A, 2010, 385: 1

[20] Lewkowski J. Arkivoc, 2001, 2: 17

[21] Shimizu K, Satsuma A. Energy Environ Sci, 2011, 4: 3140

[22] Shi N, Liu Q Y, Wang T J, Zhang Q Ma L L. Chem Ind Eng Pro (石宁, 刘琪英, 王铁军, 张琦, 马隆龙. 化工进展), 2012, 31: 792

[23] Chen W W, Li C X. [MS Dissertation]. Beijing: Beijing Univ Chem Technol (陈文文, 李春喜. [硕士论文]. 北京: 北京化工大学), 2012

[24] An S Y, Jin L H, Hu D Y, Zhang Y P, Xue W, Yang S. Chem World (安 士云, 金林红, 胡德禹, 张钰萍, 薛伟, 杨松. 化学世界), 2012, (7): 441

[25] Jiang N, Qi W, Huang R L, Su X R, He Z M. Chem Ind Eng Pro (姜楠, 齐葳, 黄仁亮, 苏欣荣, 何志敏. 化工进展), 2011, 30: 1937

[26] Hu L, Sun Y, Lin L. Chem Ind Eng Pro (胡否, 孙勇, 林鹿. 化工进 展), 2011, 30: 1711

[27] Zhang Z Y, Zhang Z C, Li J, Dai H, Li L X. Chem Res Appl (张正源, 张 宗才, 李洁, 戴红, 李立新. 化学研究与应用), 2010, 22: 257

[28] Yang F L, Liu Q S, Bai X F, Du Y G. Modern Chem Ind (杨风丽, 刘启 顺, 白雪芳, 杜昱光. 现代化工), 2009, 29: 18

[29] Wang J, Zhang C P, Ouyang P K. Chem Ind Eng Pro (王军, 张春鹏, 欧阳平凯. 化工进展), 2008, 28: 702

[30] Wang J J, Xu W J, Ren J W, Liu X H, Lu G Z, Wang Y Q. Green Chem, 2011, 13: 2678

[31] Yang F L, Liu Q S, Yue M, Bai X F, Du Y G. Chem Commun, 2011, 47: 4469

[32] Bicker M, Kaiser D, Ott L, Vogel H.J Supercrit Fluid, 2005, 36: 118

[33] Moreau C, Finiels A, Vanoye L. J Mol Catal A, 2006, 253: 165

[34] Li C Z, Zhao Z K, Wang A Q Zheng M Y, Zhang T. Carbohydr Res, 2010, 345: 1846

[35] Qi X H, Watanabe M, Aida T M, Smith R L. Green Chem, 2009, 11: 1327

[36] Lai D M, Deng L, Li J A, Liao B, Guo Q X, Fu Y. ChemSusChem, 2011, 4: 55

[37] Roman-Leshkov Y, Chheda J N, Dumesic J A. Science, 2006, 312: 1933

[38] Roman-Leshkov Y, Dumesic J A. Top Catal, 2009, 52: 297

[39] Shimizu K, Uozumi R, Satsuma A. Catal Commun, 2009, 10: 1849

[40] Tuercke T, Panic S, Loebbecke S. Chem Eng Technol, 2009, 32: 1815

[41] Qi X H, Watanabe M, Aida T M, Smith R L. Green Chem, 2008, 10: 799

[42] Li C Z, Zhao Z B K, Cai H L, Wang A Q, Zhang T. Biomass Bioenerg, 2011, 35: 2013

[43] Zhao H B, Holladay J E, Brown H, Zhang Z C. Science, 2007, 316: 1597

[44] Yong G, Zhang Y G, Ying J Y. Angew Chem, Int Ed, 2008, 47: 9345

[45] Zhang Y M, Pidko E A, Hensen E J M. Chem-Eur J, 2011, 17: 5281

[46] Ilgen F, Ott D, Kralisch D, Reil C, Palmberger A, Konig B. Green Chem, 2009, 11: 1948

[47] Pidko E A, Degirmenci V, Van Santen R A, Hensen E J M. Angew Chem, Int Ed, 2010, 49: 2530

[48] Zhang Z H, Zhao Z B. Bioresour Technol, 2011, 102: 3970

[49] Li C Z, Zhang Z H, Zhao Z B K. Tetrahedron Lett, 2009, 50: 5403

[50] Hu S Q Zhang Z F, Song J L, Zhou Y X, Han B X. Green Chem, 2009, 11: 1746

[51] Chen T M, Lin L. Chin J Chem, 2010, 28: 1773

[52] Zhang Z H, Wang Q, Xie H B, Liu W J, Zhao Z B. ChemSusChem, 
2011, 4: 131

[53] Pagan-Torres Y J, Wang T F, Gallo J M R, Shanks B H, Dumesic J A. ACS Catal, 2012, 2: 930

[54] Nikolla E, Roman-Leshkov Y, Moliner M, Davis M E. ACS Catal, 2011, 1: 408

[55] Wang J J, Ren J W, Liu X H, Xi J X, Xia Q N, Zu Y H, Lu G Z, Wang Y Q. Green Chem, 2012, 14: 2506

[56] Yasuda M, Nakamura Y, Matsumoto J, Yokoi H, Shiragami T. Bull Chem Soc Jpn, 2011, 84: 416

[57] Wang T F, Pagan-Torres Y J, Combs E J, Dumesic J A, Shanks B H. Top Catal, 2012, 55: 657

[58] Stahlberg T, Sorensen M G, Riisager A. Green Chem, 2010, 12: 321

[59] Takagaki A, Ohara M, Nishimura S, Ebitani K. Chem Commun, 2009: 6276

[60] Watanabe M, Aizawa Y, Iida T, Nishimura R, Inomata H. Appl Catal A, 2005, 295: 150

[61] Watanabe M, Aizawa Y, Iida T, Aida T M, Levy C, Sue K, Inomata H. Carbohydr Res, 2005, 340: 1925

[62] Yan H P, Yang Y, Tong D M, Xiang X, Hu C W. Catal Commun, 2009, 10: 1558

[63] Huang R L, Qi W, Su R X, He Z M. Chem Commun, 2010, 46: 1115

[64] Stahlberg T, Rodriguez-Rodriguez S, Fristrup P, Riisager A. Chem-Eur J, 2011, 17: 1456

[65] Sheldon R. Chem Commun, 2001: 2399

[66] Zhang Z H, Wang W Q, Liu X Y, Wang Q, Li W X, Xie H B, Zhao Z B K. Bioresour Technol, 2012, 112: 151

[67] Zhang Z H, Zhao Z B K. Bioresour Technol, 2010, 101: 1111

[68] Zhang Z H, Zhao Z B K. Carbohydr Res, 2009, 344: 2069

[69] Li C Z, Wang Q, Zhao Z B K. Green Chem, 2008, 10: 177

[70] Li C Z, Zhao Z K B. Adv Synth Catal, 2007, 349: 1847

[71] Swatloski R P, Spear S K, Holbrey J D, Rogers R D. J Am Chem Soc, 2002, 124: 4974

[72] Rinaldi R, Palkovits R, Schuth F. Angew Chem, Int Ed, 2008, 47: 8047

[73] Su Y, Brown H M, Huang X, Zhou X-D, Amonette J E, Zhang Z C. Appl Catal A, 2009, 361: 117

[74] Qi X H, Watanabe M, Aida T M, Smith R L. Cellulose, 2011, 18: 1327

[75] Zhang Y T, Du H B, Qian X H, Chen E Y X. Energy Fuel, 2010, 24: 2410

[76] Wu S C, Wang C L, Gao Y J, Zhang S C, Ma D, Zhao Z B. Chin J Catal (吴树昌, 王春雷, 高勇军, 张少春, 马丁, 赵宗保. 催化学报), 2010, 31: 1157

[77] Binder J B, Raines R T. J Am Chem Soc, 2009, 131: 1979

[78] Haworth W N, Jones W G M. J Chem Soc, 1944: 667

[79] Antal M J, Mok W S L, Richards G N. Carbohydr Res, 1990, 199: 111

[80] Newth F H. Adv Carbohydr Chem, 1951, 6: 83

[81] Amarasekara A S, Williams L D, Ebede C C. Carbohydr Res, 2008, 343: 3021

[82] Pidko E A, Degirmenci V, Van Santen R A, Hensen E J M. Inorg Chem, 2010, 49: 10081

[83] Roman-Leshkov Y, Moliner M, Labinger J A, Davis M E. Angew Chem, Int Ed, 2010, 49: 8954

[84] Hopkins K T, Wilson W D, Bender B C, Mccurdy D R, Hall J E, Tidwell R R, Kumar A, Bajic M, Boykin D W. J Med Chem, 1998, 41: 3872

[85] Del Poeta M, Schell W A, Dykstra C C, Jones S, Tidwell R R, Czarny A, Bajic M, Kumar A, Boykin D, Perfect J R. Antimicrob Agents Ch, 1998, 42: 2495

[86] Howarth O W, Morgan G G, Mckee V, Nelson J. J Chem Soc, Dalton Trans, 1999: 2097
[87] Richter D T, Lash T D. Tetrahedron Lett, 1999, 40: 6735

[88] Benahmed-Gasmi A S, Frere P, Jubault M, Gorgues A, Cousseau J, Garrigues B. Synth Met, 1993, 56: 1751

[89] Hui Z, Gandini A. Eur Polym J, 1992, 28: 1461

[90] Amarasekara A S, Green D, Williams L D. Eur Polym J, 2009, 45: 595

[91] Ma J P, Du Z T, Xu J, Chu Q H, Pang Y. ChemSusChem, 2011, 4: 51

[92] Ma J P, Wang M, Du Z T, Chen C, Gao J, Xu J. Polym Chem, 2012, 3: 2346

[93] Mehdi H, Bodor A, Lantos D, Horvath I T, De Vos D E, Binnemans K. J Org Chem, 2007, 72: 517

[94] Yoon H J, Choi J W, Jang H S, Cho J K, Byun J W, Chung W J, Lee S M, Lee Y S. Synlett, 2011: 165

[95] Cottier L, Descotes G, Lewkowski J, Skowronski R, Viollet E. J Heterocycl Chem, 1995, 32: 927

[96] Sheldon R A. Stud Surf Sci Catal, 1991, 59: 33

[97] Van Deurzen M P J, Van Rantwijk F, Sheldon R A. J Carbohydr Chem, 1997, 16: 299

[98] Amarasekara A S, Green D, Mcmillan E. Catal Commun, 2008, 9: 286

[99] Verdeguer P, Merat N, Gaset A. J Mol Catal, 1993, 85: 327

[100] Partenheimer W, Grushin V V. Adv Synth Catal, 2001, 343: 102

[101] Moreau C, Durand R, Pourcheron C, Tichit D. Stud Surf Sci Catal, 1997, 108: 399

[102] Carlini C, Patrono P, Galletti A M R, Sbrana G, Zima V. Appl Catal A, 2005, 289: 197

[103] Navarro O C, Canos A C, Chornet S I. Top Catal, 2009, 52: 304

[104] Nie J F, Liu H C. Pure Appl Chem, 2012, 84: 765

[105] Halliday G A, Young R J, Grushin V V. Org Lett, 2003, 5: 2003

[106] Takagaki A, Takahashi M, Nishimura S, Ebitani K. ACS Catal, 2011, 1: 1562

[107] Xiang X, He L, Yang Y, Guo B, Tong D M, Hu C W. Catal Lett, 2011, 141: 735

[108] Yang Z Z, Deng J, Pan T, Guo Q X, Fu Y. Green Chem, 2012, 14: 2986

[109] Moore J A, Kelly J E. Macromolecules, 1978, 11: 568

[110] Moore J A, Kelly J E. J Polym Sci Pol Chem, 1978, 16: 2407

[111] Moore J A, Kelly J E. Polymer, 1979, 20: 627

[112] Moore J A, Kelly J E. J Polym Sci Pol Chem, 1984, 22: 863

[113] Gandini A, Silvestre A J D, Pascoal Neto C, Sousa A F, Gomes M. J Polym Sci Pol Chem, 2009, 47: 295

[114] Gomes M, Gandini A, Silvestre A J D, Reis B. J Polym Sci Pol Chem, 2011, 49: 3759

[115] Jiang M, Liu Q, Zhang Q, Ye C, Zhou G Y. J Polym Sci Pol Chem, 2012, 50: 1026

[116] Ma J P, Pang Y, Wang M, Xu J, Ma H, Nie X.J Mater Chem, 2012, 22: 3457

[117] Ma J P, Yu X F, Xu J, Pang Y. Polymer, 2012, 53: 4145

[118] Wu L B, Mincheva R, Xu Y T, Raquez J M, Dubois P. Biomacromolecules, 2012, 13: 2973

[119] Eerhart A J J E, Faaij A P C, Patel M K. Energy Environ Sci, 2012, 5: 6407

[120] Gandini A. Polym Chem, 2010, 1: 245

[121] Gandini A, Coelho D, Gomes M, Reis B, Silvestre A.J Mater Chem, 2009, 19: 8656

[122] Gandini A. Macromolecules, 2008, 41: 9491

[123] Moreau C, Belgacem M N, Gandini A. Top Catal, 2004, 27: 11

[124] Werpy T, Petersen G. In: Top Value Added Chemicals from Biomass. Volume I: Results of Screening for Potential Candidates from Sugars and Synthesis Gas. Top 12 Candidate Summary Bios. Oak Ridge: US Department of Energy Report, 2004. 21

[125] Saha B, Dutta S, Abu-Omar M M. Catal Sci Technol, 2012, 2: 79 
[126] Vinke P, Van Dam H E, Van Bekkum H, Centi G, Trifiro F. Stud Surf Sci Catal, 1990, 55: 147

[127] Hughes M D, Xu Y J, Jenkins P, Mcmorn P, Landon P, Enache D I, Carley a F, Attard G A, Hutchings G J, King F, Stitt E H, Johnston P, Griffin K, Kiely C J. Nature, 2005, 437: 1132

[128] Hashmi A S K, Hutchings G J. Angew Chem, Int Ed, 2006, 45: 7896

[129] Taarning E, Nielsen I S, Egeblad K, Madsen R, Christensen C H. ChemSusChem, 2008, 1: 75

[130] Gorbanev Y Y, Klitgaard S K, Woodley J M, Christensen C H, Riisager A. ChemSusChem, 2009, 2: 672

[131] Casanova O, Iborra S, Corma A. ChemSusChem, 2009, 2: 1138

[132] Casanova O, Iborra S, Corma A. J Catal, 2009, 265: 109

[133] Pasini T, Piccinini M, Blosi M, Bonelli R, Albonetti S, Dimitratos N, Lopez-Sanchez J A, Sankar M, He Q Kiely C J, Hutchings G J, Cavani F. Green Chem, 2011, 13: 2091

[134] Gupta N K, Nishimura S, Takagaki A, Ebitani K. Green Chem, 2011, 13: 824

[135] Gorbanev Y, Kegnæs S, Riisager A. Top Catal, 2011, 54: 1318

[136] Gorbanev Y Y, Kegnæs S, Riisager A. Catal Lett, 2011, 141: 1752

[137] Davis S E, Houk L R, Tamargo E C, Datye A K, Davis R J. Catal Today, 2011, 160: 55

[138] Kroger M, Prusse U, Vorlop K D. Top Catal, 2000, 13: 237

[139] Ribeiro M L, Schuchardt U. Catal Commun, 2003, 4: 83

[140] Fukuoka A, Dhepe P L. Angew Chem, Int Ed, 2006, 45: 5161

[141] Yan N, Zhao C, Luo C, Dyson P J, Liu H C, Kou Y. J Am Chem Soc, 2006, 128: 8714

[142] Luo C, Wang S, Liu H C. Angew Chem, Int Ed, 2007, 46: 7636

[143] Deng W P, Tan X S, Fang W H, Zhang Q H, Wang Y. Catal Lett, 2009, 133: 167

[144] Van De Vyver S, Geboers J, Dusselier M, Schepers H, Vosch T, Zhang L, Van Tendeloo G, Jacobs P A, Sels B F. ChemSusChem, 2010, 3: 698

[145] Ding L N, Wang A Q, Zheng M Y, Zhang T. ChemSusChem, 2010, 3 : 818

[146] Geboers J, Van De Vyver S, Carpentier K, De Blochouse K, Jacobs P, Sels B. Chem Commun, 2010, 46: 3577

[147] Palkovits R, Tajvidi K, Ruppert A M, Procelewska J. Chem Commun, 2011, 47: 576

[148] Miyazawa T, Koso S, Kunimori K, Tomishige K. Appl Catal A, 2007, 318: 244

[149] Balaraju M, Rekha V, Prasad P S S, Devi B L A P, Prasad R B N, Lingaiah N. Appl Catal A, 2009, 354: 82

[150] Alhanash A, Kozhevnikova E F, Kozhevnikov I V. Catal Lett, 2008 120: 307

[151] Hamzah N, Nordin N M, Nadzri A H A, Nik Y A, Kassim M B, Yarmo M A. Appl Catal A, 2012, 419: 133

[152] Ma L, He D H. Chin J Catal (马兰, 贺德华. 催化学报), 2009, 30 471

[153] Yuan Z L, Wu P, Gao J, Lu X Y, Hou Z Y, Zheng X M. Catal Lett, 2009, 130: 261

[154] Furikado I, Miyazawa T, Koso S, Shimao A, Kunimori K, Tomishige K. Green Chem, 2007, 9: 582

[155] Musolino M G, Scarpino L A, Mauriello F, Pietropaolo R. ChemSusChem, 2011, 4: 1143

[156] Yin A Y, Guo X Y, Dai W L, Fan K N. Green Chem, 2009, 11: 1514

[157] Yu W Q, Zhao J, Ma H, Miao H, Song Q, Xu J. Appl Catal A, 2010 383: 73

[158] Zhao J, Yu W Q, Chen C, Miao H, Ma H, Xu J. Catal Lett, 2010, 134: 184

[159] Dasari M A, Kiatsimkul P P, Sutterlin W R, Suppes G J. Appl Catal A, 2005, 281: 225

[160] Huang Z W, Cui F, Kang H X, Chen J, Zhang X Z, Xia C G. Chem Ma- ter, 2008, 20: 5090

[161] Chaminand J, Djakovitch L, Gallezot P, Marion P, Pinel C, Rosier C. Green Chem, 2004, 6: 359

[162] Wang S, Liu H C. Catal Lett, 2007, 117: 62

[163] Zhou J X, Zhang J, Guo X W, Mao J B, Zhang S G. Green Chem, 2012, 14: 156

[164] Miyazawa T, Koso S, Kunimori K, Tomishige K. Appl Catal A, 2007, 329: 30

[165] Maris E P, Ketchie W C, Murayama M, Davis R J. J Catal, 2007, 251 : 281

[166] Maris E P, Davis R J.J Catal, 2007, 249: 328

[167] Jiang T, Zhou Y X, Liang S G, Liu H Z, Han B X. Green Chem, 2009 , 11: 1000

[168] Feng J, Fu H Y, Wang J B, Li R X, Chen H, Li X J. Catal Commun, 2008, 9: 1458

[169] Feng J, Xiong W, Jia Y, Wang J, Liu D, Chen H, Li X. Chin J Catal (冯 建, 熊伟, 贾云, 王金波, 刘德蓉, 陈华, 李贤均. 催化学报), 2011, 32: 1545

[170] Ma L, He D H, Li Z P. Catal Commun, 2008, 9: 2489

[171] Vasiliadou E S, Heracleous E, Vasalos I A, Lemonidou A A. Appl Catal B, 2009, 92: 90

[172] Musolino M G, Scarpino L A, Mauriello F, Pietropaolo R. Green Chem, 2009, 11: 1511

[173] Feng J, Wang J B, Zhou Y F, Fu H Y, Chen H, Li X J. Chem Lett, 2007, 36: 1274

[174] Xia S, Yuan Z, Wang L, Chen P, Hou Z. Appl Catal A, 2011, 403: 173

[175] Huang J H, Chen J X. Chin J Catal (黄金花, 陈吉祥. 催化学报), 2012, 33: 790

[176] Jimenez-Morales I, Vila F, Mariscal R, Jimenez-Lopez A. Appl Catal $B, 2012,117: 253$

[177] Yu W Q, Xu J, Ma H, Chen C, Zhao J, Miao H, Song Q. Catal Commun, 2010, 11: 493

[178] Liang C H, Ma Z Q, Ding L, Qiu J S. Catal Lett, 2009, 130: 169

[179] Balaraju M, Rekha V, Prasad P S S, Prasad R B N, Lingaiah N. Catal Lett, 2008, 126: 119

[180] Wang S A, Zhang Y C, Liu H C. Chem-Asian J, 2010, 5: 1100

[181] Clark I. Ind Eng Chem, 1958, 50: 1125

[182] Tanikella M S S R. US Patent 4404411. 1983

[183] Werpy T A, Frye Jr. J G, Zacher A H, Miller D J. US Patent 6841085. 2005

[184] Banu M, Sivasanker S, Sankaranarayanan T M, Venuvanalingam P. Catal Commun, 2011, 12: 673

[185] Sun J, Liu H. Green Chem, 2011, 13: 135

[186] Zhou J H, Zhang M G, Zhao L, Li P, Zhou X G, Yuan W K. Catal Today, 2009, 147: S225

[187] Ji N, Zhang T, Zheng M, Wang A, Wang H, Wang X, Chen J G. Angew Chem, Int Ed, 2008, 47: 8510

[188] Ji N, Zhang T, Zheng M, Wang A, Wang H, Wang X, Shu Y, Stottlemyer A L, Chen J G. Catal Today, 2009, 147: 77

[189] Zhang Y H, Wang A Q, Zhang T. Chem Commun, 2010, 46: 862

[190] Zheng M Y, Wang A Q, Ji N, Pang J F, Wang X D, Zhang T. ChemSusChem, 2010, 3: 63

[191] Zhao G H, Zheng M Y, Wang A Q, Zhang T. Chin J Catal (赵冠鸿, 郑 明远, 王爱琴, 张涛. 催化学报), 2010, 31: 928

[192] Liu Y, Luo C, Liu H C. Angew Chem, Int Ed, 2012, 51: 3249

[193] Pang J F, Zheng M Y, Wang A Q, Zhang T. Ind Eng Chem Res, 2011, 50: 6601

[194] Li C Z, Zheng M Y, Wang A Q, Zhang T. Energy Environ Sci, 2012, 5: 6383

[195] Zhou L K, Wang A Q Li C Z, Zheng M Y, Zhang T. ChemSusChem, 2012, 5: 932

[196] Kurosaka T, Maruyama H, Naribayashi I, Sasaki Y. Catal Commun, 


\title{
Graphical Abstract
}

Chin. J. Catal., 2013, 34: 492-507 doi: 10.1016/S1872-2067(11)60501-9

\begin{abstract}
Advances in selective catalytic transformation of ployols to value-added chemicals
MA Jiping, YU Weiqiang, WANG Min, JIA Xiuquan, LU Fang, XU Jie*

Dalian Institute of Chemical Physics, Chinese Academy of Sciences; University of Chinese Academy of Sciences
\end{abstract}

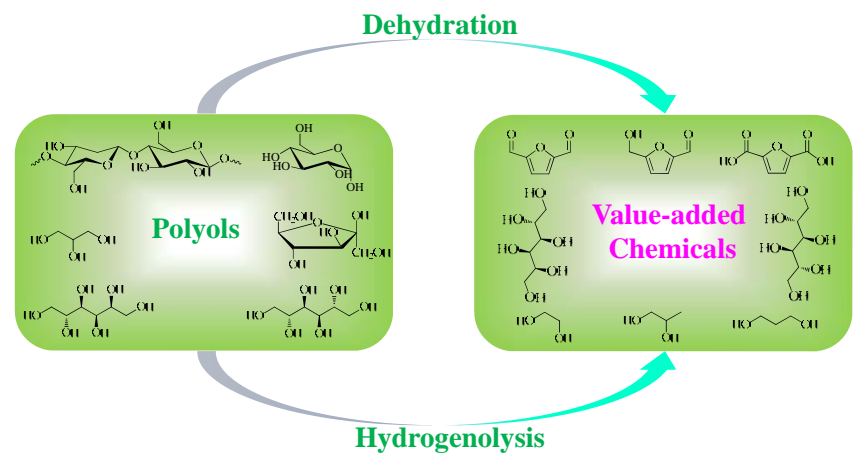

The synthesis of selected value-added chemicals from polyols by dehydration and hydrogenolysis methods is reviewed.

2008, 9: 1360

[197] Gong L F, Lu Y, Ding Y J, Lin R H, Li J W, Dong W D, Wang T, Chen W M. Chin J Catal (龚否峰, 吕元, 丁云杰, 林荣和, 李经纬, 董文 达, 王涛, 陈维苗. 催化学报), 2009, 30: 1189

[198] Qin L Z, Song M J, Chen C L. Green Chem, 2010, 12: 1466

[199] Gong L F, Lu Y A, Ding Y J, Lin R H, Li J W, Dong W D, Wang T, Chen W M. Appl Catal A, 2010, 390: 119

[200] Oh J, Dash S, Lee H. Green Chem, 2011, 13: 2004

[201] Nakagawa Y, Shinmi Y, Koso S, Tomishige K. J Catal, 2010, 272: 191

[202] Huang L, Zhu Y L, Zheng H Y, Ding G Q, Li Y W. Catal Lett, 2009,
131: 312

[203] Zhu S H, Zhu Y L, Hao S L, Chen L G, Zhang B, Li Y W. Catal Lett, 2012, 142: 267

[204] Amada Y, Shinmi Y, Koso S, Kubota T, Nakagawa Y, Tomishige K. Appl Catal B, 2011, 105: 117

[205] Chen Ch L, Song M J, Qin L Zh. J Nanjing Univ Technol (Natur Sci $E d$ ) (陈长林, 宋敏洁, 秦丽珍. 南京工业大学学报 (自然科学 版)), 2011, 33: 1

[206] Gallo J M R, Alonso D M, Mellmer M A, Dumesic J A. Green Chem, 2013, 15: 85

\section{催化选择转化多羟基化合物制备高附加值化学品研究进展}

\author{
马继平 ${ }^{\mathrm{a}}$, 于维强 ${ }^{\mathrm{a}}$, 王敏 ${ }^{\mathrm{a}}$, 贾秀全 ${ }^{\mathrm{a}, \mathrm{b}}$, 路 芳 ${ }^{\mathrm{a}}$, 徐 杰 ${ }^{\mathrm{a},}{ }^{*}$ \\ $\mathrm{a}$ 中国科学院大连化学物理研究所, 催化基础国家重点实验室, 洁净能源国家实验室, 辽宁大连 116023 \\ b 中国科学院大学, 北京100049
}

摘要: 对近年来催化转化多羟基化合物制备5-羟甲基糠醛、乙二醇、1,2-丙二醇、1,3-丙二醇等高附加值化学品进行了综述. 分析 了果糖、葡萄糖、纤维素等不同结构的碳水化合物制5-羟甲基糠醛存在的挑战, 并对相应的解决方法进行了总结. 对于5-羟甲基 糠醛的转化, 我们重点讨论了 5-羊圣甲基糠醛选择性氧化制备2,5-二甲酰基呋喃和2,5-呋喃二甲酸以及它们作为聚合单体的潜在应 用. 概述了催化氢解纤维素、糖醇、甘油等多羟基化合物制备乙二醇、1,2-丙二醇、1,3-丙二醇等二元醇的方法, 并对可能的机 理进行了讨论. 依据近年来多羟基化合物催化选择性转化制备高附加值化学品的研究现状, 对今后的研究热点进行了展望.

关键词: 生物质; 催化; 呋喃衍生物; 多羟基化合物; 可再生资源

收稿日期: 2012-11-02. 接受日期: 2012-12-14. 出版日期: 2013-03-20.

*通讯联系人. 电话/传真: (0411)84379245; 电子信箱: xujie@dicp.ac.cn

基金来源：国家自然科学基金(21233008, 21203183和21103174).

本文的英文电子版(国际版)由Elsevier出版社在ScienceDirect上出版(http://www.sciencedirect.com/science/journal/187220). 